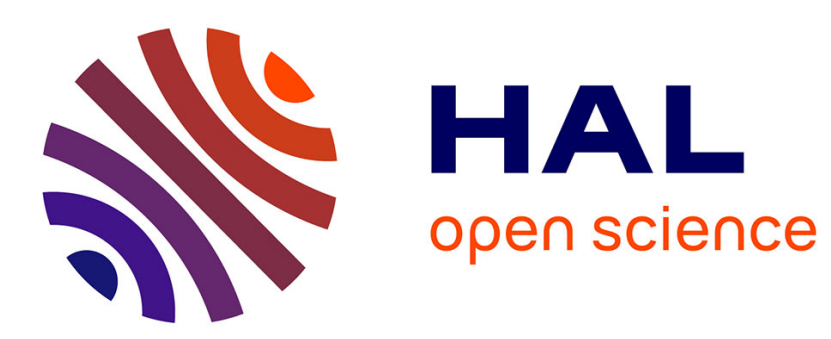

\title{
Estimation of total lightning from various storm parameters: A cloud-resolving model study
}

\author{
Christelle Barthe, Wiebke Deierling, Mary C. Barth
}

\section{To cite this version:}

Christelle Barthe, Wiebke Deierling, Mary C. Barth. Estimation of total lightning from various storm parameters: A cloud-resolving model study. Journal of Geophysical Research: Atmospheres, 2010, 115, pp.D24202. 10.1029/2010JD014405 . hal-00961370

\section{HAL Id: hal-00961370 \\ https://hal.science/hal-00961370}

Submitted on 3 Sep 2021

HAL is a multi-disciplinary open access archive for the deposit and dissemination of scientific research documents, whether they are published or not. The documents may come from teaching and research institutions in France or abroad, or from public or private research centers.
L'archive ouverte pluridisciplinaire HAL, est destinée au dépôt et à la diffusion de documents scientifiques de niveau recherche, publiés ou non, émanant des établissements d'enseignement et de recherche français ou étrangers, des laboratoires publics ou privés. 


\title{
Estimation of total lightning from various storm parameters: A cloud-resolving model study
}

\author{
Christelle Barthe, ${ }^{1,2}$ Wiebke Deierling, ${ }^{1}$ and Mary C. Barth ${ }^{1}$ \\ Received 23 April 2010; revised 23 July 2010; accepted 25 August 2010; published 16 December 2010.
}

[1] Because explicit prediction of the electrical activity in storms is computationally expensive and the processes are still poorly understood, an attractive way to predict lightning flash rates in numerical models is to rely on correlations between the flash rate and available model parameters. Predicted flash rates can be used for applications such as the parameterization to infer lightning-produced nitrogen oxides. In this study, the potential for six model parameters (precipitation ice mass, ice water path, ice mass flux product, updraft volume, maximum vertical velocity, and cloud top height) to predict lightning rate has been investigated in a cloud-resolving model framework. The Weather Research and Forecasting model (WRF) is used to simulate two different storms: the 10 July 1996 severe storm that occurred over the High Plains and the 13 July 2005 airmass thunderstorm near Huntsville, Alabama. It is shown that the WRF model reproduces the structure of the two storms. Results show that the maximum updraft velocity gives a good flash rate proxy for the severe storm. The ice mass flux product and precipitation ice mass can reproduce the flash rate trend but not the magnitude. The flash rate estimated from the cloud top height does not match the observed flash rate trend and value of the severe storm, but is in good agreement for the airmass thunderstorm. The ice water path predicts flash rate fairly well for the severe storm, but overpredicts it for the airmass thunderstorm. The updraft volume predicts flash rate poorly for both storms.

Citation: Barthe, C., W. Deierling, and M. C. Barth (2010), Estimation of total lightning from various storm parameters: A cloud-resolving model study, J. Geophys. Res., 115, D24202, doi:10.1029/2010JD014405.

\section{Introduction}

[2] Forecasting the electrical activity of a storm is a difficult task because of the complexity of the processes leading to cloud electrification and to lightning flash propagation. Today only a few mesoscale models with an electrification and lightning parameterization attempt to simulate the whole life cycle of the electric charges in a thunderstorm [Helsdon et al., 1992; Mansell et al., 2002; Barthe and Pinty, 2007a]. Simulating the electrical activity of a storm is challenging as some of the processes involved in cloud electrification and lightning propagation are poorly understood and remain topics that are still under investigation. For example, the noninductive charging mechanism is generally believed to play a dominant role in thunderstorm electrification [Reynolds et al., 1957; Williams and Lhermitte, 1983; Dye et al., 1989; Rutledge et al., 1992; Carey and Rutledge, 1996; Petersen et al., 1999; Latham et al., 2007], but its parameterization in cloud resolving models is based on laboratory experiments [Takahashi, 1978; Jayaratne et al., 1983; Saunders et al., 1991], which can lead to different

\footnotetext{
${ }^{1}$ National Center for Atmospheric Research, Boulder, Colorado, USA.

${ }^{2}$ Now at Laboratoire de l'Atmosphère et des Cyclones, CNRS, MétéoFrance, Université de La Réunion, Saint-Denis, La Réunion, France.
}

Copyright 2010 by the American Geophysical Union. 0148-0227/10/2010JD014405 electrical cloud structures and lightning flash rates [Helsdon et al., 2001; Mansell et al., 2005; Altaratz et al., 2005; Kuhlman et al., 2006; Barthe and Pinty, 2007b]. Another limitation of these complex electrical schemes is their computational cost, which prevents them from being used in forecasting models.

[3] Predicting lightning flash rate is a necessity for estimating the production of nitrogen oxides $\left(\mathrm{NO}_{\mathrm{x}}\right)$ from lightning. The lightning $-\mathrm{NO}_{\mathrm{x}}$ parameterization relies on storm parameters as proxies for lightning flash rate. In global chemical transport models, lightning flash rate has been estimated by storm parameters such as cloud top height [Horowitz et al., 2003; Hudman et al., 2007; Emmons et al., 2010; Jourdain et al., 2010], the upward cloud mass flux [Allen and Pickering, 2002], the convective precipitation rate [Meijer et al., 2001], and a combination of updraft velocity and cloud thickness [Grewe et al., 2001]. Cloud-scale chemical transport models estimate lightning flash rate using maximum vertical velocity [Pickering et al., 1998; Salzmann et al., 2008] or the collision rate between graupel and ice crystals [Wang and Prinn, 2000]. In addition, predicting lightning flash rate can be beneficial for aviation and human safety. Conversely, lightning data can be used to infer characteristics (e.g., storm intensity) of thunderstorms. For example, in regions where radar and satellite coverage is sparse, detection of lightning, which is much more economical than radar or satellite platforms, is an appealing way to gain more information on storm characteristics. 
[4] Because the correlations between the lightning flash rate and available model parameters is a useful way to predict lightning flash rates, in this study we test six storm parameters as proxies for lightning flash rate in a cloudresolving model framework to evaluate their ability in estimating flash rates. Storm parameters that we test herein and that have shown a good correlation with lightning density or flash rate include ice water path [Petersen et al., 2005a], precipitation ice mass [Blyth et al., 2001; Prigent et al., 2005; Latham et al., 2007; Deierling et al., 2008], updraft volume [Carey and Rutledge, 1996; Wiens et al., 2005; Deierling and Petersen, 2008], graupel volume [Wiens et al., 2005; Kuhlman et al., 2006], and the precipitation and nonprecipitation ice mass flux product [Deierling et al., 2008].

[5] Previously, using cloud-resolving model simulations, McCaul et al. [2009] estimated lightning flash densities by combining and calibrating vertically integrated ice and the graupel flux near $-15^{\circ} \mathrm{C}$. Yair et al. [2010] developed a lightning potential index based on total liquid and total ice condensate mixing ratio and vertical velocity in the 0 to $-20^{\circ} \mathrm{C}$ region to provide a method for forecasting lightning. At the cloud scale, only a weak linear correlation was found between lightning flash rate and maximum updraft speed in cloud-resolving models [Kuhlman et al., 2006] and in radar observations [Deierling and Petersen, 2008]. However, Price and Rind [1992] found a power law relation between lightning flash rate and maximum updraft speed.

[6] Previous studies have shown that flash rates are strongly affected by the local charge separation and the charge redistribution in the cloud in the context of the vertical air motion. Simplifying Vonnegut's theory [Vonnegut, 1963], Williams [1985] deduced a fifth-power relationship between the storm height defined at the echo top height and the flash rate. To take into account the difference in cloud dynamics between continental and maritime storms, Price and Rind [1992] derived two separate parameterizations (one for continental, the other for maritime conditions) linking the cloud top height to the maximum updraft intensity (wmax). Boccippio [2002] demonstrated that the ocean parameterization of Price and Rind [1992] yields predictions of storm updraft velocity inconsistent with satellite observations, and is inconsistent with Vonnegut's theory. A detailed scale analysis [Boccippio, 2002] connecting storm electrical generator power to charge transport velocity (i.e., updraft velocity) suggests a lightning- $w_{\max }$ relationship to a higher power. Both Ushio et al. [2001] and Yoshida et al. [2009] also showed a relation between lightning flash rate and storm height or cold-cloud depth to depend on a higher power rather than a linear relationship. Thus, the Williams [1985] relationship between storm height and flash rate and the Price and Rind [1992] continental relationship between $w_{\max }$ and flash rate, which has been used extensively in other studies, are examined here.

[7] Many of these flash rate-storm parameter relationships have been derived from field experiments but have not been tested in the model framework. As mentioned above, the purpose of this study is to assess whether any of these storm parameters can be used as a proxy for the total lightning flash rate in cloud resolving models. Therefore, two cases, a nonsevere ordinary thunderstorm case that occurred on 13 July 2005 in Northern Alabama and a severe storm that occurred during the Stratospheric-Tropospheric Experiment: Radiation, Aerosols and Ozone (STERAO-A) on 10 July 1996 in northeast Colorado, are simulated with the Weather Research and Forecasting (WRF) model. The simulation results are compared to total lightning as well as to storm microphysical and dynamical observations from dualpolarimetric and Doppler radar data. In the following, the flash rate-storm parameter relationships from the literature are presented and are calculated with the WRF model output. These calculations are evaluated with observations of both the storm parameters and the lightning flash rate. Then the ability of the WRF-derived relationships to estimate lightning flash rate using a cloud-resolving model is discussed.

\section{Flash Rate-Cloud Parameter Relationships}

[8] This study focuses on six different flash rate-cloud parameter relationships that were demonstrated to be robust or that were widely used in past studies. These relationships are described here. The six tested cloud parameters are precipitation ice mass, ice water path, precipitation and nonprecipitation ice mass flux product, updraft volume, maximum vertical velocity, and cloud top height, which are easily extracted from the model. Recently, Yair et al. [2010] developed a lightning potential index $(L P I)$ to aid forecasting of lightning. While their $L P I$ is shown to correlate well with lightning flash rate, a relationship predicting flash rate as a function of $L P I$ was not given. Thus, we do not include the $L P I$ as part of this study, but do discuss whether the $L P I$ correlates with lightning flash rate in section 9.

\subsection{Precipitation Ice Mass}

[9] Deierling et al. [2008] used ground-based dualpolarimetric radar and total lightning data to investigate the relationship between total lightning activity and precipitation ice mass on a storm scale. From a total of 11 thunderstorms (130 data points), they found a linear relationship between the flash rate $\left(f\right.$, in flashes per minute or fl. $\left.\min ^{-1}\right)$ and the precipitation ice mass $\left(p_{m}\right.$, in $\left.\mathrm{kg}\right)$ for temperatures colder than $-5^{\circ} \mathrm{C}$ :

$$
f=3.4 \times 10^{-8} p_{m}-18.1
$$

Deierling et al. [2008] found the correlation between precipitation ice mass and lightning flash rate to be $r=0.94$. When their data was separated by storm type, they found the correlation to be higher for severe storms than for ordinary single-cell type thunderstorms. For individual thunderstorms, relationships of graupel volume as determined by dual-polarimetric radar analysis using a particle identification algorithm and total lightning have also been found by other investigators such as Wiens et al. [2005].

\subsection{Ice Water Path}

[10] On the basis of Tropical Rainfall Measuring Mission (TRMM) Lightning Imaging Sensor (LIS) and Precipitation Radar (PR) observations, results from Petersen et al. [2005a] suggest that on a global scale, lightning activity is linearly related to the vertically (or column) integrated ice water path (referred to as ice water path in the following text). Their results also show this relationship to be relatively invariant between land, ocean, and coastal regimes. 
This is consistent with observations from Blyth et al. [2001], Prigent et al. [2005], and Latham et al. [2007] that found or summarized a relationship between $85 \mathrm{GHz}$ brightness temperatures and total lightning activity from the TRMM Microwave Instrument (TMI) and LIS sensor.

[11] Following Petersen et al. [2005a], the flash density $\left(F D\right.$ in fl. $\mathrm{km}^{-2}$ day $^{-1}$ ) for thunderstorms over land can be deduced from the ice water path $\left(I W P\right.$, in $\left.\mathrm{kg} \mathrm{m}^{-2}\right)$ :

$$
F D=33.33 \times I W P-0.17
$$

These per-unit-area quantities are collocated by virtue of the TRMM-PR/LIS combination. The scatter in the ice water path in the above equation is shown to be $\sim 80 \%$ of the average ice water path. Thus individual storms may not always be represented well by this same linear relationship.

[12] To use this relationship in our study, the ice water path is computed in the same manner as described by Petersen et al. [2005a]. The IWP is computed from the model output by vertically integrating the mass of both nonprecipitating and precipitating ice above the $-10^{\circ} \mathrm{C}$ isotherm and for radar reflectivities greater than $18 \mathrm{dBZ}$ in each column. The IWP calculation can be quite sensitive to the radar reflectivity threshold. For example, a simulation that predicts higher reflectivity than observed would enlarge the region for the IWP calculation and thereby alter its magnitude. In our study, we use flash rate (fl. $\min ^{-1}$ ) instead of flash density (fl. $\mathrm{km}^{-2}$ day $^{-1}$ ). We therefore assume that the $0.5^{\circ} \times 0.5^{\circ}$ grids used in the Petersen et al. [2005a] study would represent an individual storm that is observed or simulated in our study.

\subsection{Precipitation and Non-Precipitation Ice Mass Flux Product}

[13] Using ground-based dual-Doppler and polarimetric radar data, Deierling [2006] and Deierling et al. [2008] have shown that for the 11 storms (130 data points) they studied, the precipitation and nonprecipitation ice mass flux product is well correlated $(r=0.96)$ to total lightning activity $(f)$ following:

$$
f=9.0 \times 10^{-15}\left(f_{p} \times f_{n p}\right)+13.4 .
$$

The ice mass flux product is defined as the product of the precipitation and the nonprecipitation ice mass fluxes for temperatures colder than $-5^{\circ} \mathrm{C}$. The precipitation ice mass flux $\left(f_{p}\right.$ in $\left.\mathrm{kg} \mathrm{m} \mathrm{s}^{-1}\right)$ and the nonprecipitation ice mass flux $\left(f_{n p}\right.$ in $\left.\mathrm{kg} \mathrm{s}^{-1}\right)$ are [Deierling et al., 2008]:

$$
\begin{gathered}
f_{p}=\left[\left(-v_{p}\right) q_{p}\right] \times \rho \times \Delta x \times \Delta y \times \Delta z \\
f_{n p}=\left[\left(d i v_{h n p}\right) q_{n p}\right] \times \rho \times \Delta x \times \Delta y \times \Delta z,
\end{gathered}
$$

where $v_{p}$ is the mass-weighted terminal fall speed of the precipitation ice particles and $d i v_{h n p}$ is the horizontal divergence. Furthermore, $q_{p}$ and $q_{n p}$ are the mixing ratio of the precipitation and nonprecipitation particles, $\rho$ is the density of air, and $\Delta x, \Delta y$, and $\Delta z$ are the grid spacing following the $x, y$, and $z$ directions, respectively.

[14] In this study, the ice mass fluxes are computed in a similar way with two exceptions. To be more correct, the precipitation ice mass flux was calculated using $\left(w-v_{p}\right)$. A comparison of the predicted flux product and flash rate using both methods showed that the model calculated flux product was greater when $w$ was omitted, but the flash rate had negligible changes. In Deierling et al. [2008], the horizontal divergence was used to compute the nonprecipitation ice mass flux owing to the fact that the nonprecipitation ice mass cannot be computed in the updraft core from the radar measurements. Following Deierling et al. [2008], it was found from model results that the product of horizontal divergence and nonprecipitation ice mass is proportional to $\left(w-v_{n p}\right) \times \rho \times \Delta x \times \Delta y \times \Delta z$, which is used as the nonprecipitation ice mass flux in this modeling study. Here, $v_{n p}$ is the terminal fall speed of the nonprecipitation ice particles, which depends on the hydrometeor sizes.

\subsection{Updraft Volume}

[15] Deierling and Petersen [2008] studied the link between updraft characteristics and the total flash rate from 11 storms (130 data points) observed in different climate regimes and of different intensities. In particular, they found a strong linear correlation $(r=0.93)$ between the updraft volume with the vertical velocity $w>5 \mathrm{~m} \mathrm{~s}^{-1}$ as well as $w>$ $10 \mathrm{~m} \mathrm{~s}^{-1}$ and the total flash rate. The best correlation coefficient was found for vertical velocities exceeding $5 \mathrm{~m} \mathrm{~s}^{-1}$ [Deierling and Petersen, 2008]

$$
f=6.75 \times 10^{-11} w_{5}-13.9,
$$

where $w_{5}$ is the updraft volume $\left(\mathrm{m}^{3}\right)$ above the $-5^{\circ} \mathrm{C}$ isotherm with velocities $>5 \mathrm{~m} \mathrm{~s}^{-1}$. Generally, these results are in agreement with Wiens et al. [2005], who found a correlation coefficient of 0.95 between the total flash rate and the normalized updraft volume for $w>10 \mathrm{~m} \mathrm{~s}^{-1}$ for the 29 June 2000 STEPS storm. Kuhlman et al. [2006] simulated the electrification and lightning activity of this same storm and also found that the updraft volume with $w>10 \mathrm{~m} \mathrm{~s}^{-1}$ is correlated to the total lightning activity, but with a lag of $4 \mathrm{~min}$.

\subsection{Cloud Top Height}

[16] Vonnegut [1963] first derived fundamental scaling relations of thunderstorm electrical generator power to charge transport and storm geometry. On the basis of the original scaling arguments by Vonnegut [1963], Williams [1985] simplified Vonnegut's approach and suggested that the flash rate is a function of the fifth power of the storm height. Williams [1985] tested this prediction using three different sets of flash rate and cloud top height data in the United States. The power law exponents for the three data sets are in good agreement with the predicted exponent of 5 . Price and Rind [1992] adapted the sets of field measurements by Williams [1985]. Their relationship between the flash rate $(f)$ and the cloud top height $(H$, in $\mathrm{km})$ for continental storms is as follows:

$$
f=3.44 \times 10^{-5} H^{4.9}
$$

[17] This relationship is used in our study. The cloud top height is computed as the maximum height of the $20 \mathrm{dBZ}$ echo, and only storms over continents are considered. Note that using data from the TRMM satellite, Ushio et al. [2001] showed that the flash rate increases exponentially with 
storm height. Also, on the basis of coincident data from PR and LIS aboard TRMM, Yoshida et al. [2009] found that the number of flashes per second per convective cloud is proportional to the fifth power of the cold-cloud depth.

\subsection{Maximum Vertical Velocity}

[18] Power law relationships between the lightning flash rate and the maximum vertical velocity have been widely used to study the production of nitrogen oxides from lightning [Pickering et al., 1998; Fehr et al., 2004; Salzmann et al., 2008; Barthe and Barth, 2008]. A Price and Rind [1992]-based relationship between flash rate and $w_{\max }\left(\mathrm{m} \mathrm{s}^{-1}\right)$ has been used extensively in these previous studies. The power law from Price and Rind [1992] for continental storms is based on scaling arguments previously derived by Vonnegut [1963] and simplified by Williams [1985] (see section 2.5) and the assumption that the updraft intensity is positively correlated with the cloud top height:

$$
f=5 \times 10^{-6} \times w_{\max }^{k}
$$

The exponent $k$ was derived empirically from satellite data to be 4.5 for continental deep convection [Price and Rind, 1992]. The variance associated with this relation was not reported by Price and Rind [1992], but is expected to be of a similar magnitude as the other relationships on the basis of their scatterplots.

[19] In our study, we calculate the flash rate as written above using $k=4.5$ and refer to this relationship as PR92 hereafter. Several previous studies have applied an adjustment factor to this equation. For example, Fehr et al. [2004] scaled the equation by a factor of 0.26 , Salzmann et al. [2008] used a factor of 0.06, and Barthe and Barth [2008] used a factor of 0.19. Pickering et al. [1998] adjusted the exponent to obtain better agreement between observed and modeled lightning flash rate. As described in section 3, the flash rate computed in this study is based on an adjusted value for $w_{\max }$ producing a reduction in the flash rate of the same order as Fehr et al. [2004]. In addition, we also discuss the results using the scaling factor of Barthe and Barth [2008] (hereinafter referred to as BB08).

\section{Methodology and Model Description}

[20] To assess whether any of these storm parameters can be used as a proxy for the total lightning flash rate in cloudresolving models, two different storms, one severe and one ordinary thunderstorm, are simulated. First, simulated and observed radar reflectivities from the storms are compared to evaluate the simulated storm structure, intensity, and morphology. The aim of this study is to test the relationships in a model framework. Because the simulated storm is only a representation of the observed storm and not an exact depiction, the observed storm parameter-lightning flash rate relationships described in section 2 are not directly applied in the model. For example, Pickering et al. [1998] and Fehr et al. [2004] did not directly apply the flash rate- $w_{\max }$ relationship from Price and Rind [1992], but applied an adjustment factor so that the simulated flash rate better matched the observed flash rate. To minimize the bias between model and observational parameters, a regression between the observed and modeled storm parameters is calculated (see section 7). The resulting equation is then applied to the relationships presented in section 2 to calculate the flash rate estimated from model parameters.

[21] The Weather Research and Forecasting model version 2.2 [Skamarock et al., 2005] is used for the simulations because of its ability to represent reasonably convective storms. The model solves the conservative (flux-form), nonhydrostatic compressible equations using a split-explicit time-integration method on the basis of a third-order Runge-Kutta scheme [Skamarock et al., 2005; Wicker and Skamarock, 2002]. The cloud microphysics in the model is configured to use a single moment (bulk-water) microphysics parameterization. Thus, water vapor, cloud water, rain, cloud ice, snow, and graupel (or hail) are the water reservoirs transported. Transport of the moisture fields is integrated with the Runge-Kutta scheme using fifth-order (horizontal) and third-order (vertical) upwind-biased advection operators. Cloud water and ice are represented as a monodisperse size distribution, whereas rain, snow, and graupel/hail are represented as inverse exponential size distributions.

[22] Our aim is to obtain a good representation from the model of the observed storm characteristics and their trend with time. As part of the analysis, we examine the variability in the results for simulations with different horizontal resolutions and with different cloud microphysics parameterizations.

\section{The 10 July 1996 STERAO-A Storm}

[23] The 10 July 1996 STERAO-A storm, which was an isolated severe storm, occurred along the WyomingNebraska-Colorado border and was observed during the Stratospheric-Tropospheric Experiment: Radiation, Aerosols and Ozone (STERAO-A) [Dye et al., 2000]. This storm was initially a multicellular storm that later transitioned to a supercellular storm. The 10 July 1996 STERAO-A storm was chosen for this study because it has been investigated by several groups in detail previously. For example, its electrical activity in relation to its microphysical properties was investigated by Defer et al. [2001], Lang and Rutledge [2002], and Deierling et al. [2005]. In addition, the 10 July STERAO-A storm has been simulated by several groups [Skamarock et al., 2000, 2003; Barth et al., 2001, 2007a, 2007b; Barthe et al., 2007; Barthe and Barth, 2008; Ott et al., 2010] to study transport, chemistry, and lightning-produced $\mathrm{NO}_{\mathrm{x}}$ characteristics.

\subsection{Observations}

[24] During STERAO-A, dual-polarimetric radar data were collected by the Colorado State University-University of Chicago-Illinois State Water Survey (CSU-CHILL) National Radar Facility's S-band radar [Brunkow et al., 2000], and total lightning was recorded by the Office Nationale d'Etudes et de Recherches Aérospatiales (ONERA) three-dimensional lightning VHF-interferometer system [Laroche et al., 1994; Defer et al., 2001]. From these data, several microphysical and dynamical storm parameters such as updraft volume, maximum updraft speed, precipitation ice mass, ice water path, and the product of precipitation and nonprecipitation ice mass fluxes were computed. 
[25] To examine cloud particle interactions in the turbulent mixed phase regions of thunderstorms, the dual-polarimetric radar data were used to identify bulk microphysical hydrometeor types [Vivekanandan et al., 1999; Straka et al., 2000]. As described in more detail in Deierling et al. [2008], the NCAR particle identification algorithm (PID) was used to determine precipitation ice and nonprecipitation ice. Then appropriate reflectivity $(Z)$-mass content $(M)$ relationships of the kind $M=a Z^{b}$ were chosen from the literature that represent different thunderstorm ice types to compute precipitation and nonprecipitation ice masses. Sensitivity studies performed in Deierling [2006] and Deierling et al. [2008] show that computed ice mass values may vary by an order of magnitude, depending on the chosen Z-M relationships, particle identification membership functions, and Cartesian grid sizes. However, the actual ice mass trends remain very similar and thus are considered robust.

[26] In the case of the 10 July 1996 storm, radar data from only one radar were available and a three-dimensional wind field was determined using the NCAR Variational Doppler Radar Assimilation System (VDRAS) [Sun and Crook, 1997, 2001; Crook and Sun, 2004]. The retrieval of the $3-\mathrm{D}$ wind field for the storms investigated herein is described in detail in Deierling and Petersen [2008]. The 3-D wind field retrievals do contain errors; however, Deierling and Petersen [2008] inspected each wind retrieval analysis to check whether they give realistic results (realistic wind vectors and velocities) and concluded that the retrieval can give qualitative reliable trends of parameters such as updraft volumes.

\subsection{Configuration of the Model}

[27] The simulation performed is similar to Skamarock et al. [2000, 2003] and Barth et al. [2001, 2007a]. In the simulation, the environment is assumed to be homogeneous; thus a single thermodynamic sounding is used to initialize the storm. The thermodynamic sounding profile, obtained from sonde and aircraft data, had a convective available potential energy (CAPE) of $1850 \mathrm{~J} \mathrm{~kg}^{-1}$ and displayed strong shear, especially near the surface (for more detailed discussion of the storm environment, see Skamarock et al. [2000]). The effects of radiation, surface moisture, and surface heat fluxes are not included in the simulation. The convection is initiated with three warm $\left(3^{\circ} \mathrm{C}\right.$ perturbation $)$ bubbles oriented in a NW-to-SE line. The model domain is chosen to be $160 \times 160 \times 20 \mathrm{~km}^{3}$ in $\mathrm{x}, \mathrm{y}$, and $\mathrm{z}$ directions with $1 \mathrm{~km}$ horizontal grid spacing and 51 grid points in the vertical direction, with a variable resolution beginning at $50 \mathrm{~m}$ at the surface and stretching to $1200 \mathrm{~m}$ at the top of the domain. The simulation is integrated with a $10 \mathrm{~s}$ time step for a 3 hour period. Because the lateral boundaries are open boundaries, the convection is kept near the center of the model domain by moving the grid at $1.5 \mathrm{~m} \mathrm{~s}^{-1}$ eastward and $5.5 \mathrm{~m} \mathrm{~s}^{-1}$ southward, i.e., the zonal and meridional storm speed estimated by Skamarock et al. [2000]. For this simulation, the Lin et al. [1983] microphysics parameterization is used, in which it is assumed that the graupel/hail hydrometeor category has hail characteristics in which the size distribution intercept $N_{0 g}=4 \times 10^{4} \mathrm{~m}^{-4}$ and the hail density is $\rho_{g}=917 \mathrm{~kg} \mathrm{~m}^{-3}$.

\subsection{Results}

[28] To determine whether the storm simulated by the WRF model represents the observed storm structure, a comparison between the modeled reflectivity and the observed radar reflectivity as well as storm dynamical and microphysical parameters is performed. Focusing first on the comparison between modeled and observed reflectivity, three different stages could be identified: a multicell $(0-$ $80 \mathrm{~min}$ in the model corresponding to $2300-0030$ UTC for the observations), a transition (80-110 min corresponding to 0030-0115 UTC), and a supercell (110-180 min corresponding to 0115-0230 UTC) stage. The selection of the model time was done carefully on the basis of the examination of horizontal and vertical cross sections of the vertical velocity, radar reflectivity, and on the time series of dynamical and microphysical parameters. As an example, horizontal cross sections of the radar reflectivity at the multicell and supercell stages measured by the CSU-CHILL radar at $4.7 \mathrm{~km}$ MSL and simulated by the model at $4.5 \mathrm{~km}$ MSL are shown in Figures 1a-1d. It can be seen in Figure 1b that at 1 hour into the model simulation, the simulated storm has multiple cells. This is in agreement with the radar reflectivity measurements from the CSU-CHILL radar that indicate three main cells oriented along a NW-SE axis (Figure 1a). The reflectivity at the center of all the simulated cells reaches $50 \mathrm{dBZ}$, which is slightly smaller than the radar observations at 0015 UTC. The horizontal extension of the simulated and observed storm is fairly similar. At 2 hours, 30 minutes (Figure 1d), the storm has transitioned to the supercell stage. However, the modeled supercell has rotated to the east, while the observed storm is still oriented in a NW-SE direction (Figure 1c). The simulated radar reflectivity reaches $55 \mathrm{dBZ}$, while the observed radar reflectivity exhibits a maximum of $63 \mathrm{dBZ}$. The radar data show that the remaining NW cell transitions to the supercell during the transition from multi- to supercell stage, while it is the SE cell that transitions to the supercell in the simulation. It must be noted that the transition stage is longer in the observations compared to the simulation; therefore, the modeled supercell stage occurs in advance of the one observed with the radar.

\section{The 13 July 2005 Alabama Storm}

[29] The ordinary thunderstorm case was observed on 13 July 2005 in northern Alabama. A west-east line of single-cell storms developed after the passage of a cold front. The synoptic situation on that day was governed by a nearly stationary low-pressure area, which was a remnant of Hurricane Dennis and was situated over the Ohio Valley. A cloud band associated with the low-pressure area covered Northern Alabama until the early afternoon hours. The cloud band moved northeastward, allowing subsequent surface heating which finally led (possibly in combination with residual boundaries) to the development of a line of small, nonsevere thunderstorms just southeast of Huntsville, Alabama, around 1800 UTC. The line of small thunderstorms was aligned in a west-east direction and strengthened with time. Values for CAPE were $\sim 900 \mathrm{~J} \mathrm{~kg}^{-1}$ from the Rapid Update Cycle 2 (RUC2) analysis around the time of the line's development. An hour later several storms also developed in a line close and parallel to the first line of 

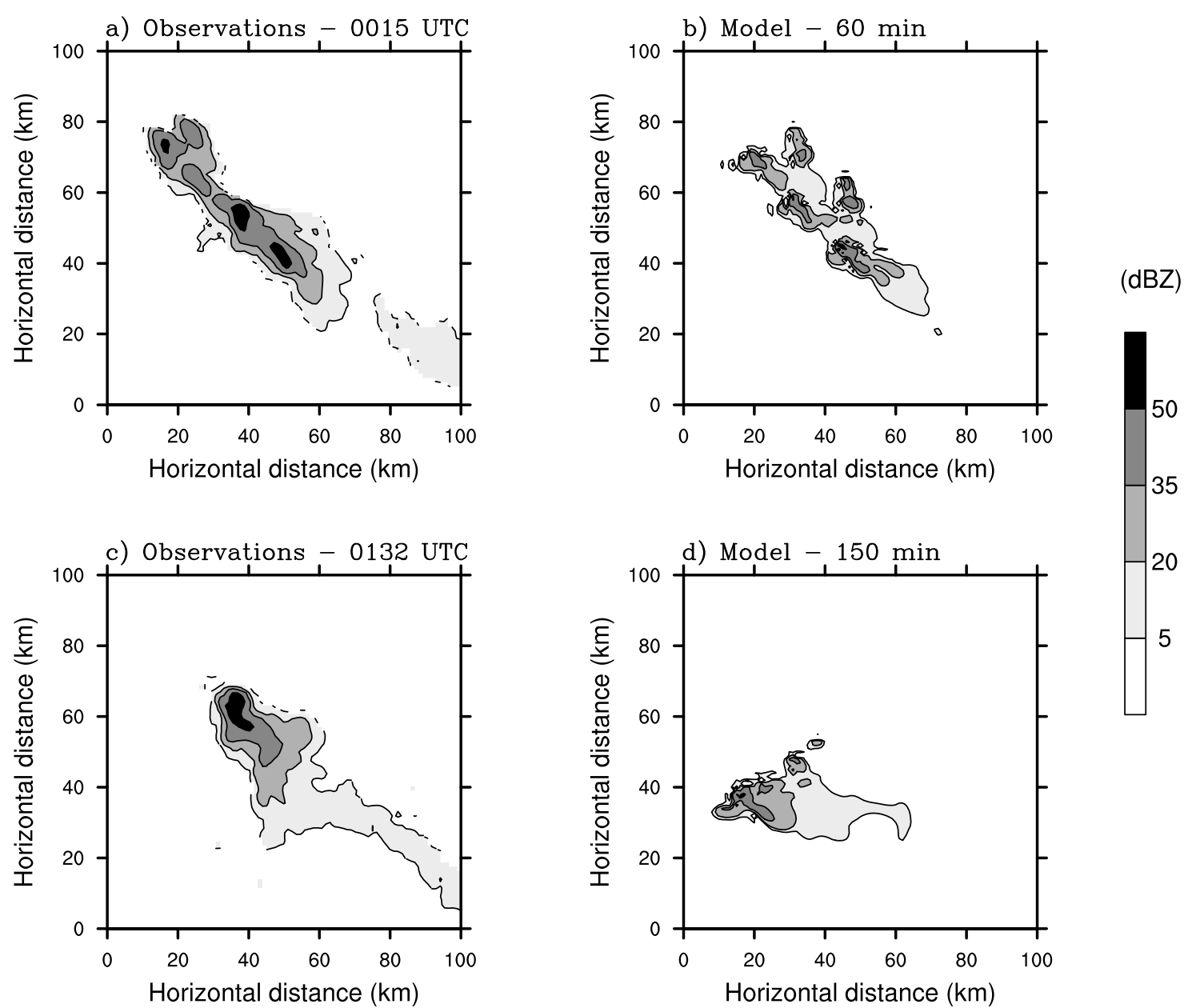

Figure 1. Observed and simulated horizontal cross sections of radar reflectivity (dBZ) for the 10 July 1996 STERAO-A storm. Observations obtained from the CSU-CHILL are displayed at 4.7 km MSL for (a) 0015 UTC and (c) 0132 UTC. WRF results are illustrated at (b) 60 min and (d) $150 \mathrm{~min}$ at $4.5 \mathrm{~km}$ MSL.

storms. By 1930 UTC, the storms strengthened further and started to merge (Figure 2a). The convection started to dissipate from 2200 UTC on moving east-southeastward out of the domain.

\subsection{Observations}

[30] Total lightning data were collected by the North Alabama Lightning Mapping Array (LMA), which is permanently installed in the Huntsville, Alabama, area [Goodman et al., 2005]. Dual-polarimetric radar data were collected from the University of Alabama Huntsville/ National Space Science and Technology Center (UAH/ NSSTC) C-band Advanced Radar for Meteorological and Operational Research (ARMOR) radar [Petersen et al., $2005 \mathrm{~b}$ ] to identify bulk microphysical hydrometeor types [Vivekanandan et al., 1999; Straka et al., 2000]. As described in Deierling et al. [2008], the NCAR PID algorithm modified for C-band dual-polarimetric radar data was used to determine precipitation and nonprecipitation ice masses. The three-dimensional wind fields were calculated from ARMOR and the nearby Hytop National Weather Service (NWS) Weather Surveillance Radar-1988 Doppler (WSR-88D) radar data by performing a dual Doppler wind synthesis using NCAR's Custom Editing and Display of Reduced Information in Cartesian Space (CEDRIC) software [Mohr et al., 1986].

\subsection{Configuration of the Model}

[31] To simulate the 13 July 2005 convection near Huntsville, Alabama, the WRF model was configured for three domains. The outer domain contains $216 \times 300$ horizontal grid points with $9-\mathrm{km}$ grid spacing. The middle and inner domains have $352 \times 571$ and $250 \times 208$ horizontal grid points with $3 \mathrm{~km}$ and $1 \mathrm{~km}$ grid spacing, respectively. All three domains have 35 vertical levels in a stretched grid with spacing ranging from $\sim 100 \mathrm{~m}$ near the surface, to $\sim 500 \mathrm{~m}$ near $2 \mathrm{~km}$, to $\sim 700 \mathrm{~m}$ near $10 \mathrm{~km}$, and $\sim 900 \mathrm{~m}$ near the top of the domain $(\sim 20 \mathrm{~km})$. The outer domain uses a modified version of the Kain-Fritsch cumulus parameterization [Kain and Fritsch, 1990, 1993; Skamarock et al., 2005], while the two inner domains do not use a cumulus parameterization. All three domains employ the Yonsei University (YSU) planetary boundary layer scheme [Noh et al., 2001], the NOAH land surface model, which is the successor to the Oregon State University scheme [Chen and Dudhia, 2001], a longwave and shortwave radiation 
a) Obs Reflectivity

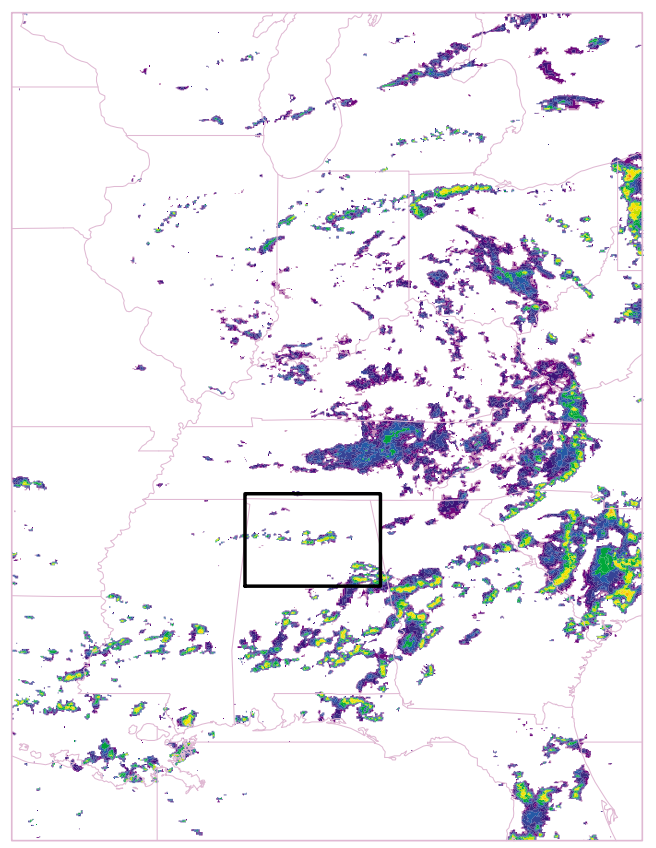

b) WRF Reflectivity

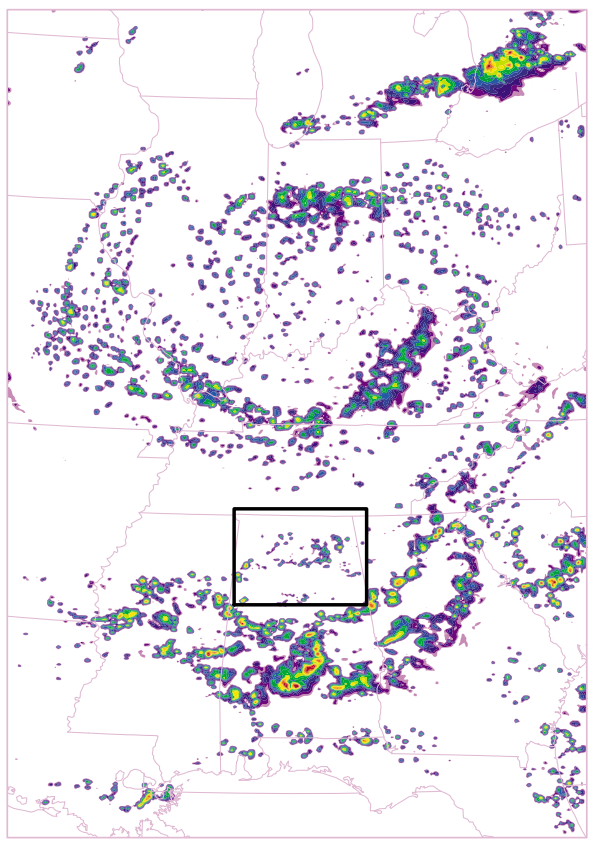

$\mathrm{dBZ}$

$\begin{array}{lllllllllllllll}5 & 10 & 15 & 20 & 25 & 30 & 35 & 40 & 45 & 50 & 55 & 60 & 65 & 70 & 75\end{array}$
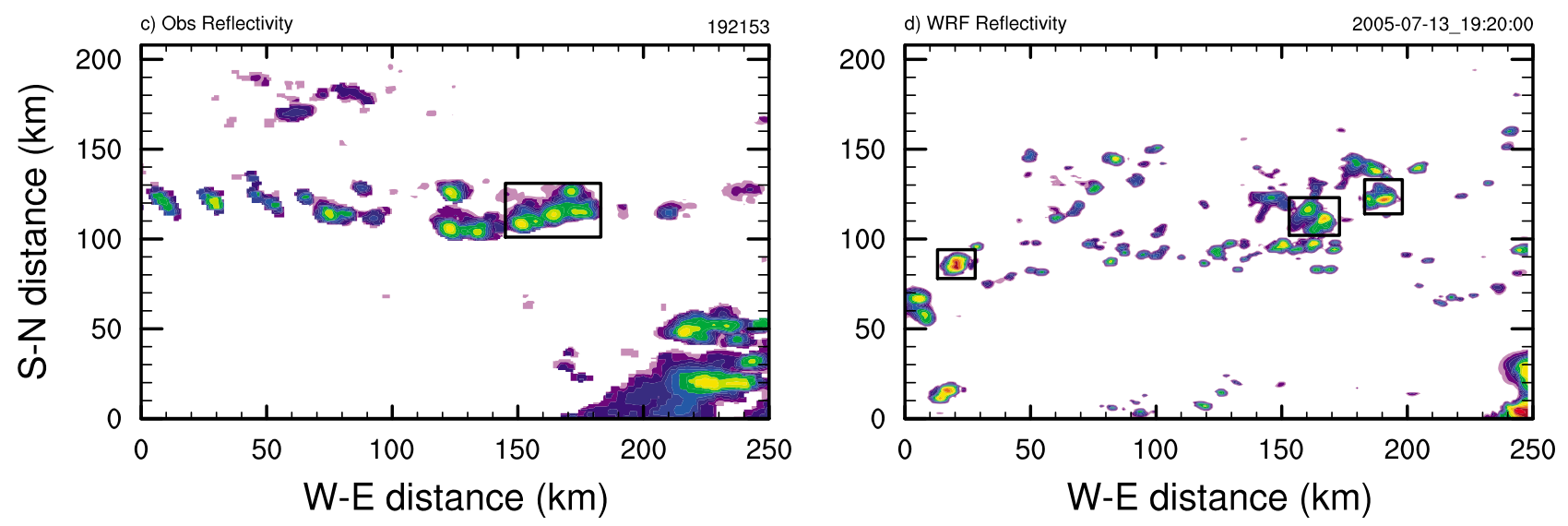

Figure 2. Observed and simulated horizontal cross sections of the composite reflectivity (dBZ), which is the same as maximum radar reflectivity in a grid cell column, for the 13 July 2005 Huntsville storm. In the top images, both observations and model results from the middle domain are shown at 1930 UTC, and the inner domain is marked by the black box. In the bottom images, the maximum radar reflectivity for the inner domain is displayed at 1922 UTC for the observations (left) and 1920 UTC for the model (right) and the observed and simulated cells considered in the study are marked by the black boxes.

parameterization [Dudhia, 1989], and the Lin et al. [1983] bulk microphysics parameterization. Several different simulations using different microphysical schemes [Lin et al., 1983; Thompson et al., 2004] and different values for the graupel/hail intercept parameter $\left(N_{0 g}\right)$ and density $\left(\rho_{g}\right)$ were performed to find the best representation of the line of convection in northern Alabama. The simulation using the Lin et al. [1983] scheme with $N_{0 g}=4 \times 10^{4} \mathrm{~m}^{-4}$ and $\rho_{g}=$ $400 \mathrm{~kg} \mathrm{~m}^{-3}$ was most consistent with the observations. The line of convection was simulated at the same location as observed, and the cells' morphology and intensity was similar to the observed ones. Additionally, these intercept parameters are representing larger graupel (not large hail), which is also consistent with the radar observations. The initial and lateral boundary conditions (updated every 3 hours) of the meteorology are obtained from North American Mesoscale operational model analyses. The simulation was integrated from 1200 UTC 13 July 2005 to 0000 UTC 14 July 2005 . We emphasize that our goal with this simulation is to produce convective cells similar in intensity to those observed to 
(a)

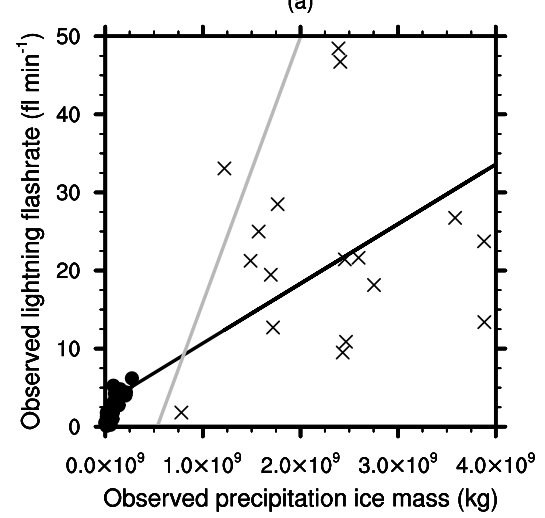

(d)

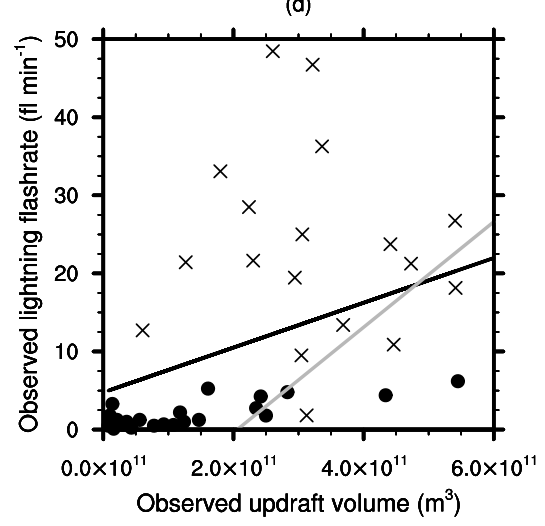

(b)

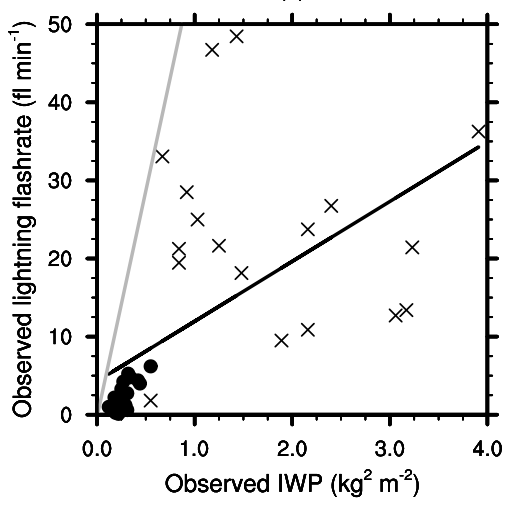

(e)

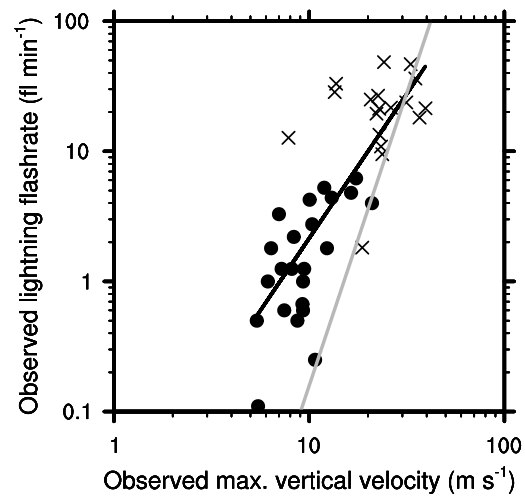

(c)

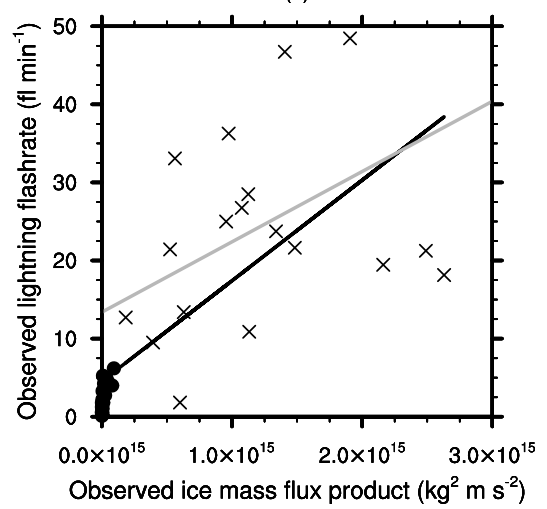

(f)

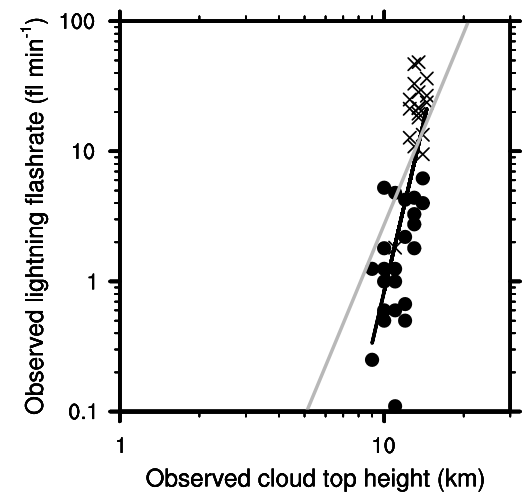

Figure 3. Scatterplots of the observed lightning flash rate versus the observed (a) precipitation ice mass, (b) ice water path, (c) precipitation and nonprecipitation ice mass flux product, (d) updraft volume, (e) maximum vertical velocity, and (f) cloud top height. Crosses and circles correspond to the 10 July STERAO-A storm and to the 13 July Alabama storm, respectively. The best fit line through data points of both storms is plotted with the black line. The shaded line is the equation from previous studies (section 2). Correlation coefficients between the observed flash rate and the observed parameters, equations for the best fit line through data points of both storms, and associated standard deviation can be found in Table 1 .

compare modeled dynamical and microphysical properties with those analyzed from the observations.

\subsection{Results}

[32] Figures $2 \mathrm{a}$ and $2 \mathrm{~b}$ show the observed composite reflectivity (equal to maximum reflectivity in a grid cell column) measured by the US Next-Generation Radars (NEXRAD) and simulated by the model for the middle domain at 1930 UTC (about 1 hour, 30 minutes after the storms initiated). One can see that the general features of the low-pressure area are similar between modeled and observed radar reflectivities. In particular, the line of storms that developed just SE of the Huntsville, Alabama, area is reproduced in the model simulation. Figures $2 \mathrm{c}$ and $2 \mathrm{~d}$ show the line of thunderstorms in this area for the innermost domain. The simulated line of storms has the same northsouth extent $(\sim 70 \mathrm{~km})$ as the observed one $(\sim 50 \mathrm{~km})$. The observed individual cells have a larger horizontal extent $(\sim 10-20 \mathrm{~km})$ than the simulated ones. In the simulation, the horizontal extent of the cells ranges from 10 to $15 \mathrm{~km}$. The maximum reflectivity of the simulated cells is higher $(>60 \mathrm{dBZ})$ than the observed maximum reflectivity $(\sim 50$ $55 \mathrm{dBZ})$. The modeled line of thunderstorm cells appears fairly similar in intensity and lifetime to those observed, but are generally smaller in horizontal extent.

\section{Comparison of Observed Storm Parameters to Previously Derived Relationships}

[33] Here we compare the observed storm parameter-flash rate relationships for data from the two storms investigated with the relationships cited in the literature to learn how well these particular storms fit with the previous work. The relationships from the previous studies (section 2), which are based on 10 s to 1000 s of storms, have substantial scatter associated with them. For example, the IWP-FD relationship of Petersen et al. [2005a] has IWP ranging from 0.05 to $0.8 \mathrm{~kg} \mathrm{~m}^{-2}$ for average IWP of 0.3 to 0.4 . Thus we expect the two storms in this study to have relationships within the scatter of the previous work, but not necessarily to follow exactly the linear relationship derived by Petersen et al. [2005a]. Note that these two storms are included in the relationships derived by Deierling et al. [2008] and Deierling and Petersen [2008] and are therefore subsets of their work.

[34] The comparison between observed storm parameterflash rate relationships for the two storms show similar behavior to the equations (Figure 3 ) for the flux product 
Table 1. Correlation Coefficient and Equation of the Regression Performed Between the Observed Storm Parameters and the Observed Lightning Flash Rate for Both the STERAO-A and Northern Alabama Cases

\begin{tabular}{lccc}
\hline & Correlation Coefficient & Regression Equation & Standard Deviation $^{\text {a }}$ \\
\hline Precipitation ice mass & 0.76 & $\mathrm{f}=7.64 \times 10^{-9} p_{m}+3.05$ & $1.05 \times 10^{-9}$ \\
Ice water path & 0.58 & $\mathrm{f}=7.67 \mathrm{IWP}+4.29$ & 1.71 \\
Ice mass flux product & 0.73 & $\mathrm{f}=1.29 \times 10^{-14}\left(f_{p} \times f_{n p}\right)+4.54$ & $1.94 \times 10^{-15}$ \\
Updraft volume & 0.38 & $\mathrm{f}=2.87 \times 10^{-11} w_{5}+4.76$ & $1.10 \times 10^{-11}$ \\
Maximum vertical velocity & 0.80 & $\mathrm{f}=1.30 \times 10^{-2} w_{\max }^{2.2}$ & $\mathrm{f}=1.71 \times 10^{-9} \mathrm{H}^{8.7}$ \\
Cloud top height & 0.74 & $\mathrm{f}$ & 1.27 \\
\hline
\end{tabular}

${ }^{\mathrm{a}}$ The standard deviation between the data values and the regression line.

relationship [Deierling et al., 2008]. The observed updraft volume-flash rate relationship for the two storms has a much larger intercept than that determined by Deierling and Petersen [2008] and has a slope smaller, but somewhat similar, to the equation. The slope (Table 1) for the precipitation ice mass-flash rate and the ice water path-flash rate relationships is 4.4 times lower in the two simulated storms than in the equations determined from previous studies, respectively. The power law equation for the maximum updraft velocity has an exponent two times higher than in the previous study of PR92, while the exponent for the cloud-top height power law equation is two times lower than the fifth exponent in the literature [Williams, 1985]. The correlation coefficient (Table 1) is higher than 0.73 for the precipitation and nonprecipitation ice mass flux product (0.73), the cloud top height (0.74), and precipitation ice mass $(0.76)$ and has the highest value for the maximum vertical velocity $(0.80)$. Hence, on the basis of these results, it is expected that the PR92 and the flux product relationships would provide reasonable estimates of flash rate, while IWP would not.

\section{Regression of the Observed and Modeled Storm Parameters}

[35] Because the model does not exactly reproduce the observations of the storm, an adjustment factor is applied to each storm parameter. If an adjustment factor were not used, differences in the dynamics and microphysics could bias the prediction of the lightning flash rate. Applying an adjustment factor is appropriate because the goal of this study is only to assess the ability of the storm parameters to predict lightning flash rates in cloud-resolving models and does not provide equations for forecast models to predict flash rate.

[36] The adjustment factor is obtained by first matching times in the model results with observation times. Then a regression is computed between the modeled and observed storm parameters for both the STERAO-A and northern Alabama cases. The regression of each of the storm parameters, precipitating ice mass, ice water path, flux product, updraft volume, maximum updraft speed, and cloud top height is shown in Figure 4. While there is much scatter in the plots, there appears to be some correlation (Table 2) for most parameters, with the best correlation occurring for the cloud top height $(r=0.81)$.

[37] We further investigated how sensitive the modeled storm parameters are to different microphysical parameterizations and different grid spacing. Several simulations were conducted for the 10 July STERAO-A storm with different microphysical parameterizations. Of these, three parameterizations, the Lin, 1983 scheme already presented, $\mathrm{N}_{0 g}=4 \times 10^{4}$ and $\rho_{g}=400 \mathrm{~kg} \mathrm{~m}^{3}$ (hereinafter referred to as N4 $\rho 4$ ), and the Thompson [2004] scheme, are compared. These three microphysical parameterizations all produced a storm similar to what was observed, especially in that the simulated storm transitioned from a multicellular storm to a supercell. To give an idea of how well the storm parameters are predicted at other model resolutions, we performed simulations of the 10 July STERAO-A storm at both a coarser and a finer resolution ( $2 \mathrm{~km}$ and $500 \mathrm{~m}$, respectively). The variations (Table 3 ) in the storm parameters among the model resolution simulations were $\sim 25 \%$ or less, with the smallest variation occurring for the cloud top height $(6 \%)$ and the greatest variation occurring for the ice mass flux product $(25 \%)$. For the three microphysics parameterization simulations, the variations were somewhat greater, with the least variation occurring for the cloud top height $(6 \%)$ and the greatest variation occurring for the flux product $(59 \%)$. Except for the flux product, these variations are less than $35 \%$ of the average value of the parameter.

\section{Simulated Flash Rate}

[38] To determine the simulated flash rate, the modeled storm parameter is adjusted according to the regression between the observations and modeled storm parameters using the regression equations listed in Table 2. These adjusted storm parameters are then inserted into the equations described in section 2 to calculate the simulated flash rate.

\subsection{The 10 July STERAO-A Storm}

[39] The observed lightning flash rate (Figure 5) for the 10 July 1996 STERAO-A storm generally has lower flash rates during the multicell and transition stages of 10-30 fl. $\mathrm{min}^{-1}$ compared to the supercell stage, where the flash rate was $40-50 \mathrm{fl} . \mathrm{min}^{-1}$. This trend is repeated by the simulated flash rate predicted by the precipitation ice mass. However, the magnitude of the flash rate predicted by the precipitation ice mass is higher than what was observed (50-60 fl. $\mathrm{min}^{-1}$ during multicell and transition stages and 64-77 fl. $\min ^{-1}$ during supercell stage). The flash rate predicted by the ice mass flux product replicates the trend of the observations fairly well. The magnitude of the flash rate predicted by the flux product is slightly lower compared to observations for the multicell and transition stages $\left(20-27 \mathrm{fl} . \mathrm{min}^{-1}\right)$, but does not increase as much (only up to $30 \mathrm{fl} . \mathrm{min}^{-1}$ ) during the supercell stage. The flash rate predicted by the ice water path $\left(\sim 40 \mathrm{fl} . \mathrm{min}^{-1}\right.$ during the multicell stage) is initially greater than observations. During 

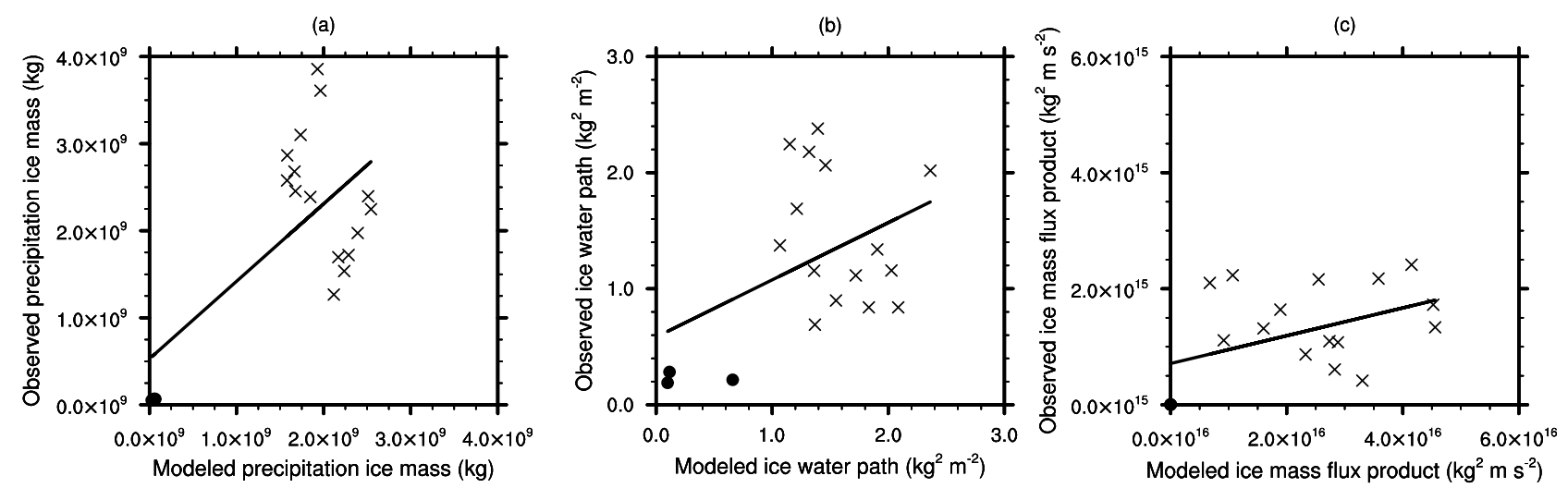

(d)
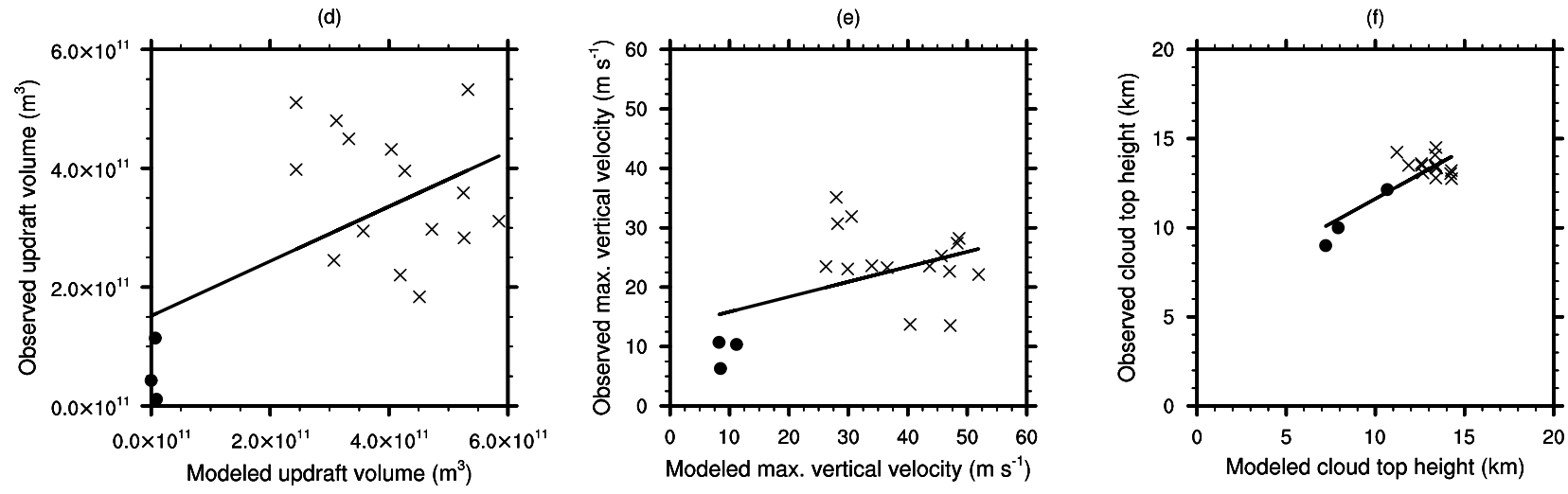

Figure 4. Scatterplots of the observed versus modeled (a) precipitation ice mass, (b) ice water path, (c) precipitation and nonprecipitation ice mass flux product, (d) updraft volume, (e) maximum vertical velocity, and (f) cloud top height for the control simulations (10 July: $1 \mathrm{~km}$ horizontal resolution, Lin, 1983 microphysics; 13 July: east cell at $1 \mathrm{~km}$ resolution). Crosses and circles correspond to the 10 July STERAO-A storm and to the 13 July Alabama storm, respectively. The best fit line through data points of both storms is plotted with the solid black line. Correlation coefficients between the observed and modeled values, equations for the best fit line through data points of both storms and associated standard deviation can be found in Table 2 .

the supercell stage, it has a somewhat similar trend to the observations and a similar magnitude (40-50 fl. $\left.\mathrm{min}^{-1}\right)$. The flash rate predicted by the maximum updraft speed from PR92, by the cloud top height, and by the updraft volume is much smaller than observed, with values less than $25 \mathrm{fl} . \mathrm{min}^{-1}$ all along the simulation. The inferred flash rate from the updraft volume does not show the distinct increase when the storm became a supercell. We also tested the Price and Rind [1992] equation multiplied by 0.19, which is the same value used by BB08 for the 10 July STERAO-A storm. For this case, $w_{\max }$ is not adjusted by the regression.
The predicted flash rate is $5-15 \mathrm{fl} . \mathrm{min}^{-1}$ during the multicell stage, similar to the observations up to 0000 UTC (1015 fl. $\min ^{-1}$ ). After $0000 \mathrm{UTC}$, the observed flash rate increases to $30 \mathrm{fl} . \mathrm{min}^{-1}$, while the flash rate estimated from BB08 remains lower than $10 \mathrm{fl} . \mathrm{min}^{-1}$ after $60 \mathrm{~min}$. During the transition stage, the predicted flash rate increases to 55 fl. $\min ^{-1}$, which occurs sooner than observed and might be related to the fact that the modeled transition stage is shorter than the observed transition stage. The flash rate then drops to $30-42$ fl. $\min ^{-1}$ during the supercell stage,

Table 2. Correlation Coefficient and Equation of the Regression Performed Between the Model and the Observed Storm Parameters for Both the STERAO-A and Northern Alabama Cases ${ }^{\mathrm{a}}$

\begin{tabular}{lccc}
\hline & Correlation Coefficient & Regression Equation & Standard Deviation \\
\hline Precipitation ice mass & 0.64 & $\mathrm{y}=0.91 \mathrm{x}+4.92 \times 10^{8}$ & 0.27 \\
Ice water path & 0.43 & $\mathrm{y}=0.49 \mathrm{x}+0.58$ & 0.26 \\
Ice mass flux product & 0.45 & $\mathrm{y}=0.024 \mathrm{x}+7.12 \times 10^{14}$ & 0.012 \\
Updraft volume & 0.55 & $\mathrm{y}=0.46 \mathrm{x}+1.52 \times 10^{11}$ & 0.17 \\
Maximum vertical velocity & 0.49 & $\mathrm{y}=0.25 \mathrm{x}+13.55$ & 0.11 \\
Cloud top height & 0.81 & $\mathrm{y}=0.55 \mathrm{x}+6.09$ & 0.10 \\
\hline
\end{tabular}

${ }^{\mathrm{a}}$ The regression performed is for the control simulations (10 July: $1 \mathrm{~km}$ horizontal resolution, Lin [1983] microphysics; 13 July: east cell at $1 \mathrm{~km}$ resolution). The last column corresponds to the standard deviation between the data values and the regression line. In the regression equation column, $x$ and $y$ correspond to the model and to the observations, respectively. 
Table 3. Average and Standard Deviation of Storm Parameters for the 10 July STERAO-A Storm Among the $500 \mathrm{~m}, 1 \mathrm{~km}$, and $2 \mathrm{~km}$ Resolution Simulations, and Among the Lin [1983] Thompson [2004] and N4 $\rho 4$ Microphysics Simulations

\begin{tabular}{lcc}
\hline & $\begin{array}{c}\text { Resolution } \\
\text { Simulations }\end{array}$ & $\begin{array}{c}\text { Microphysics } \\
\text { Simulations }\end{array}$ \\
\hline Precipitation ice mass & $2.42 \pm 0.34 \times 10^{9}$ & $3.02 \pm 0.97 \times 10^{9}$ \\
Ice water path & $1.58 \pm 0.12$ & $1.60 \pm 0.34$ \\
Ice mass flux product & $3.54 \pm 0.87 \times 10^{16}$ & $2.49 \pm 1.46 \times 10^{16}$ \\
Updraft volume & $4.37 \pm 0.74 \times 10^{11}$ & $4.22 \pm 1.31 \times 10^{11}$ \\
Maximum vertical velocity & $41.7 \pm 7.0$ & $40.2 \pm 5.9$ \\
Cloud top height & $13.53 \pm 0.76$ & $13.24 \pm 0.83$ \\
\hline
\end{tabular}

which is somewhat smaller but similar to the observations (30-47 fl. $\min ^{-1}$ ).

[40] When comparing the predicted flash rate from the $2 \mathrm{~km}$ and $500 \mathrm{~m}$ horizontal resolution simulations to the $1 \mathrm{~km}$ resolution simulation, we get generally the same result (Figure 6). That is, the flash rate predicted by the precipitation ice mass ranges from 35 to $75 \mathrm{fl}$. $\mathrm{min}^{-1}$ with a higher flash rate during the supercell stage. The flash rate predicted by the ice mass flux product remains between 20 and $30 \mathrm{fl} . \mathrm{min}^{-1}$. Flash rates predicted by ice water path, maximum vertical velocity, cloud top height, and updraft volume are all similar to the $1 \mathrm{~km}$ results. Thus, for simulations with different horizontal grid resolution of a severe, shear-driven storm, these empirical relationships are fairly robust.

[41] In comparing the predicted flash rate from the different microphysics parameterizations (Lin, 1983, Thompson, 2004, and N4 $\rho 4$ ) simulations, we find only a little variability (Figure 6). The flash rates predicted by the precipitation ice mass show some variability, depending on the scheme, with $\mathrm{N} 4 \rho 4$ microphysics generally producing flash rates less than the other two schemes. The maximum flash rate estimated from the precipitation ice mass using the N $4 \rho 4$ microphysics scheme only reaches $65 \mathrm{fl}$. $\min ^{-1}$, while it exceeds $75 \mathrm{fl}$. $\min ^{-1}$ when the Lin, 1983 and Thompson, 2004 schemes are used. The flash rates inferred by the cloud top height, the updraft volume, and the flux product are similar in magnitude in all three microphysics parameterizations. The flash rate predicted by the maximum updraft speed (PR92) is similar in magnitude to the Lin, 1983 scheme for both the Thompson, 2004 and N $4 \rho 4$ schemes. However, the Thompson, 2004 simulation has a trend similar to observations in that the flash rate increases during the supercell stage. When comparing the flash rate predicted by the BB08 equation using the Thompson, 2004 microphysics parameterization, there is a distinct increase in flash rate during the supercell stage (from 5 to $30 \mathrm{fl} . \mathrm{min}^{-1}$ ). The flash rates are still lower than observed (30 fl. $\min ^{-1}$ versus $47 \mathrm{fl} . \mathrm{min}^{-1}$ ), but tuning the 0.19 factor would likely bring the predicted flash rate into agreement with observations. In conclusion, the chosen microphysics scheme does not seem to produce significant differences in predicted lightning flash rate as long as the storm is reasonably represented.

\subsection{The 13 July Alabama Storm}

[42] The observed lightning flash rate for the 13 July 2005 storm (Figure 7) shows only a few flashes per minute $\left(<5\right.$ fl. $\left.\min ^{-1}\right)$, which were typical values for the observed storm cells. For the comparison of the observed and simulated flash rates, we calculated the flash rate for the east storm cell in the innermost domain of the model simulation (Figure 2d) because it was most similar in structure and morphology to the observed storm cells. Additionally, flash rates for two other cells are computed and discussed in comparison to the east storm cell to evaluate the representativeness of the eastern storm cell. Results show that inferred flash rates from predicted precipitation ice mass and maximum updraft speed agree best with the magnitude of the observed flash rates. The flash rate predicted by the

(a) Observations

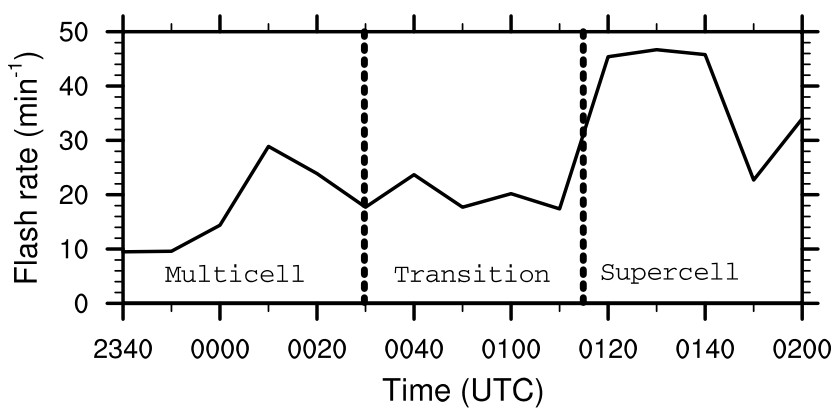

(b) WRF

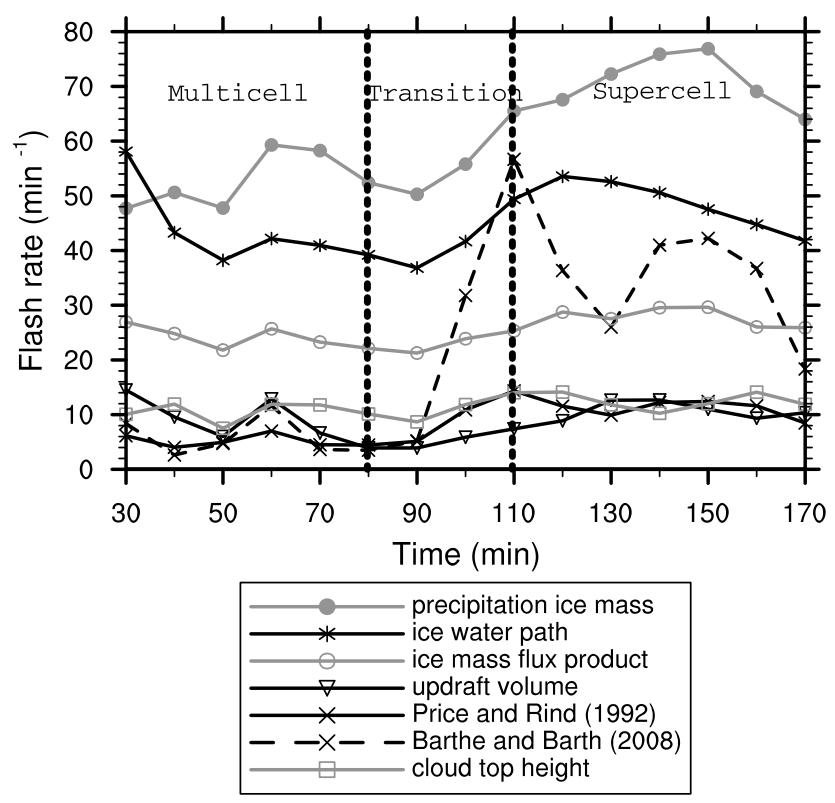

Figure 5. Temporal evolution of the (a) observed and (b) modeled flash rates (fl. $\min ^{-1}$ ). In Figure $5 \mathrm{~b}$, the flash rate is derived from the precipitation ice mass (solid shaded line with dot), the ice water path (solid black line with asterisk), the precipitation and nonprecipitation ice mass flux product (solid shaded line with circle), the updraft volume (solid black line with down triangle), the PR92 equation (solid black line with cross), the BB08 equation (dashed black line with cross), and the cloud top height (solid shaded line with square), all computed from WRF outputs. The limits of the different stages of the storm (vertical dashed lines) are indicated for the observed and the simulated storm. 

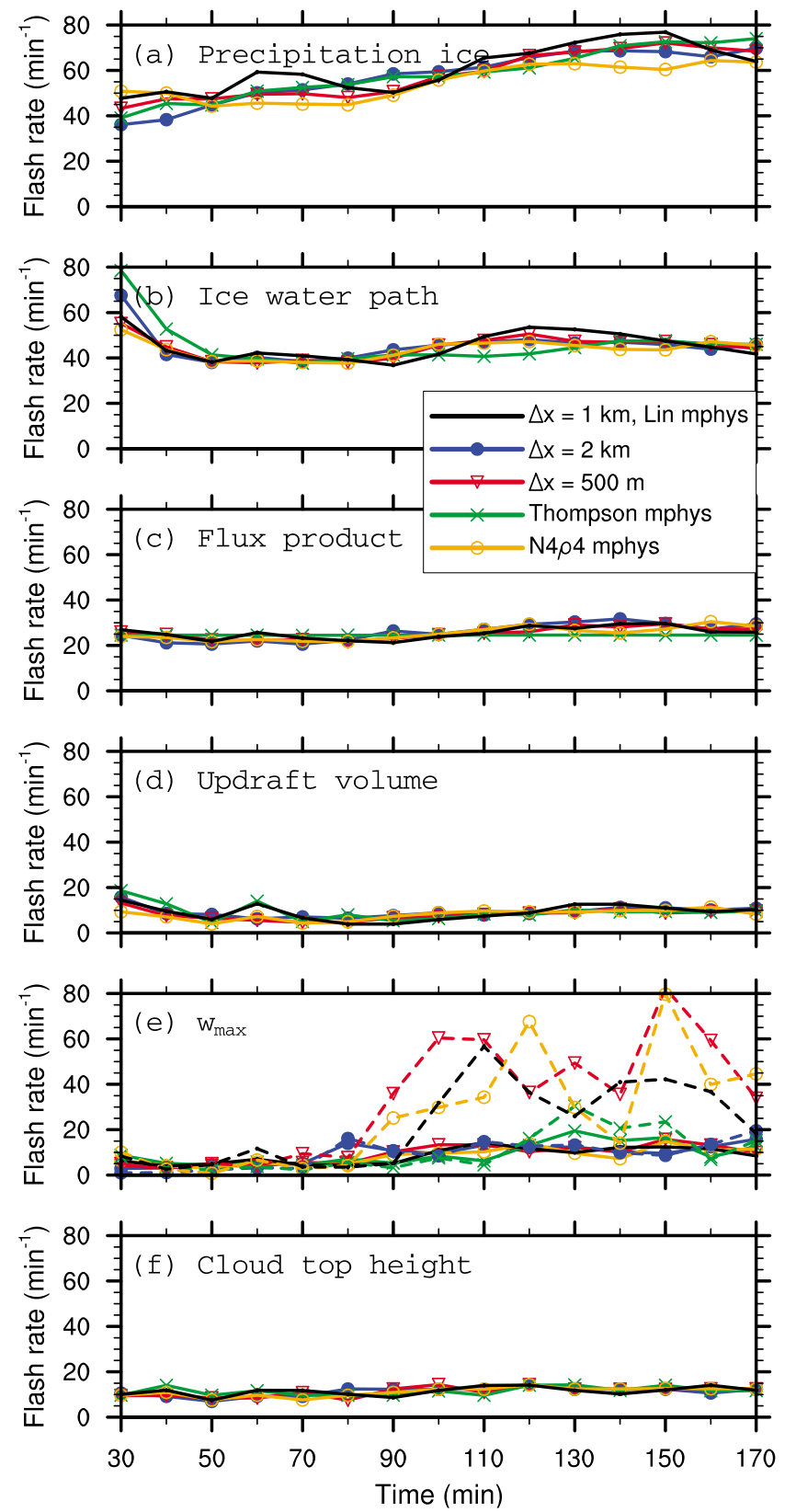

Figure 6. Temporal evolution of the modeled flash rates (fl. min $^{-1}$ ) for the 10 July STERAO-A storm control and sensitivity simulations derived from the (a) precipitation ice mass, (b) ice water path, (c) precipitation and nonprecipitation ice mass flux product, (d) updraft volume, (e) maximum vertical velocity, and (f) cloud top height. In Figure 6e the dashed lines are the flash rate derived from the BB08 equation. The black line is the control simulation $(\Delta x=$ $1 \mathrm{~km}$, Lin, 1983 microphysics), the blue line is $\Delta \mathrm{x}=2 \mathrm{~km}$, the red line is $\Delta \mathrm{x}=500 \mathrm{~m}$, the green line is the simulation using Thompson, 2004 microphysics, and the orange line is the simulation using $\operatorname{Lin}, 1983$ microphysics with $N_{0 g}=4 \times$ $10^{4} \mathrm{~m}^{-4}$ and $\rho_{g}=400 \mathrm{~kg} \mathrm{~m}^{-3}$.

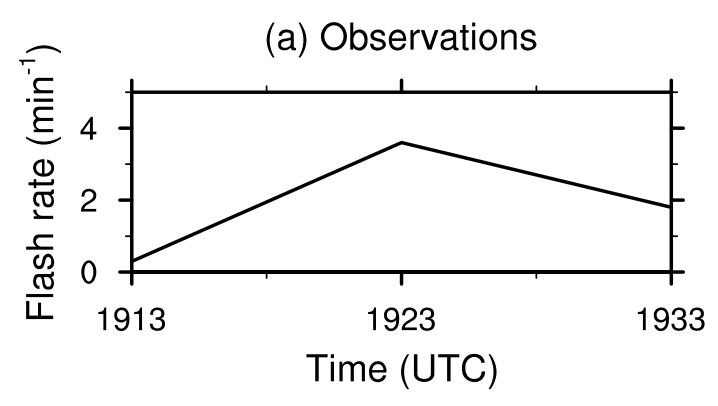

(b) WRF
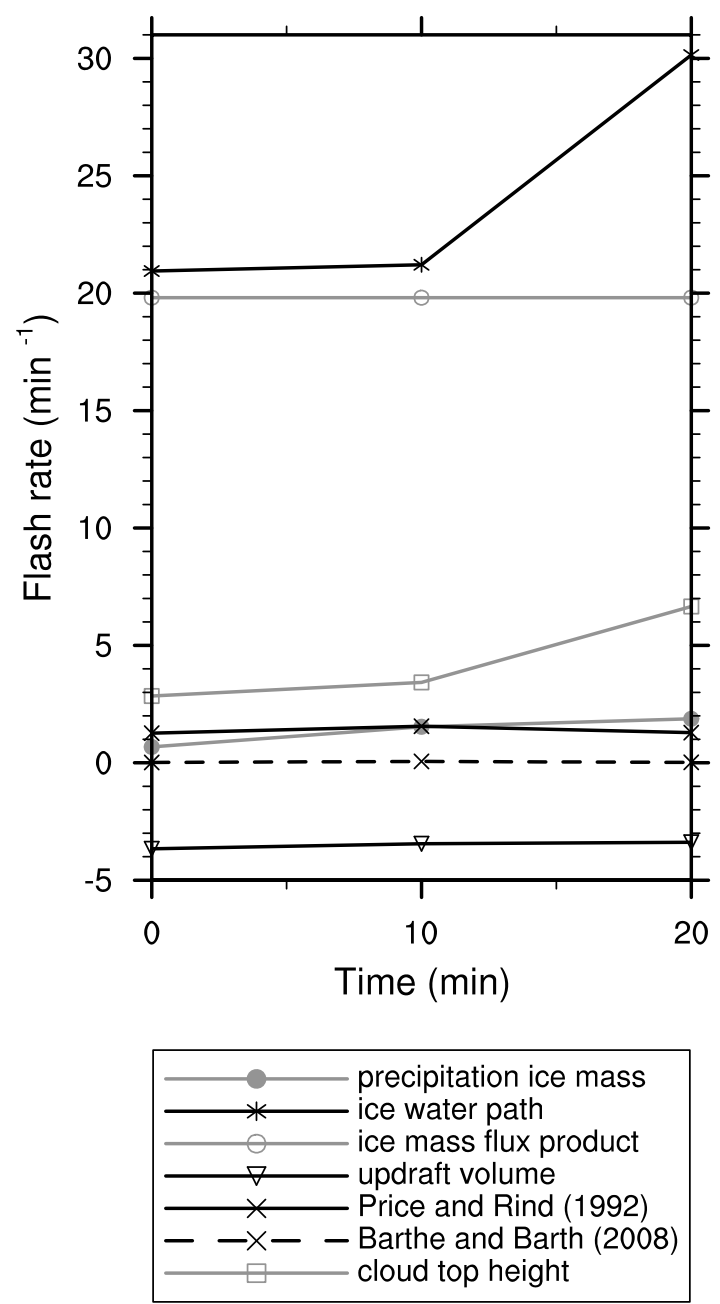

Figure 7. Temporal evolution of the (a) observed and (b) modeled flash rates $\left(\mathrm{fl} . \mathrm{min}^{-1}\right.$ ). In Figure $7 \mathrm{~b}$ the flash rate is derived from the precipitation ice mass (solid shaded line with dot), the ice water path (solid black line with asterisk), the precipitation and nonprecipitation ice mass flux product (solid shaded line with circle), the updraft volume (solid black line with down triangle), the PR92 equation (solid black line with cross), the BB08 equation (dashed black line with cross), and the cloud top height (solid shaded line with square), all computed from WRF outputs. 
updraft volume turns out to be negative, which indicates that more data points and thus a more robust storm parameterflash rate relationship are needed to yield more reliable flash rate predictions. The flash rates inferred from the flux product $\left(20 \mathrm{fl} . \mathrm{min}^{-1}\right)$ and the ice water path $(20-30 \mathrm{fl}$. $\min ^{-1}$ ) are substantially higher than observations. If the PR92 equation is used, the predicted flash rate is in the range $0.01-0.06$ fl. $\mathrm{min}^{-1}$.

[43] Two other storm cells (Figure 2d, center and west cells) were also analyzed to understand the variability of the
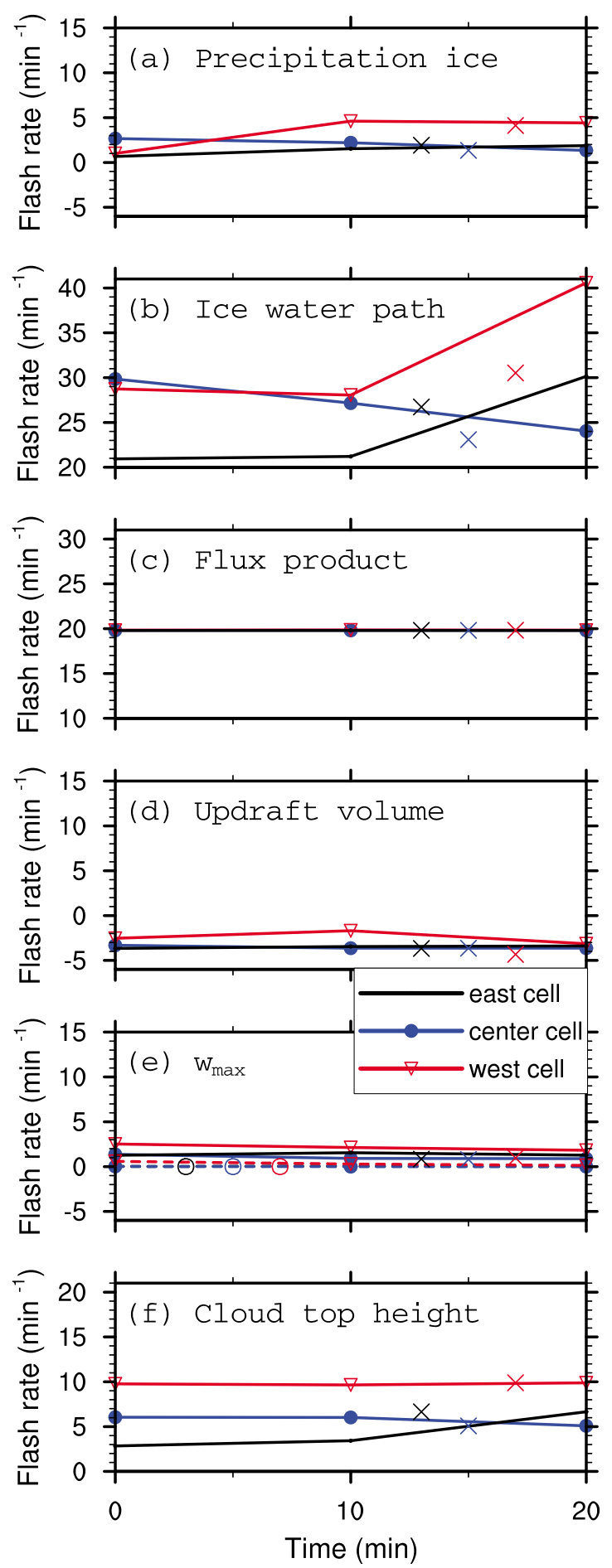

storm parameters among different storm cells. The west storm cell tended to be more intense than the central and east storm cells, with peak updraft velocities of $10-19 \mathrm{~m} \mathrm{~s}^{-1}$ (instead of $3-11 \mathrm{~m} \mathrm{~s}^{-1}$ for the east and central storm cells, and $5-11 \mathrm{~m} \mathrm{~s}^{-1}$ for the observed storm cell), and also with the highest values for the five other parameters. As a result, the flash rate predicted by the $w_{\max }$ regression is greatest for the west storm (2-3 fl. $\left.\min ^{-1}\right)$ compared to the other two storm cells (Figure 8). If the PR92 equation is used, the predicted flash rate is also increased modestly $(0.1-$ $0.6 \mathrm{fl} . \mathrm{min}^{-1}$ ) for the west storm cell. It must be noted that the updraft volume for $w>5 \mathrm{~m} \mathrm{~s}^{-1}$ is at times close to or exactly zero in the central and east storms, which is reflected in a much weaker ice mass flux product. We find that the flash rate predicted for each of the storm cells is approximately the same for the flux product calculation methods. The flash rate inferred by the $I W P$ has a $50 \%$ variability and is much higher than observed. The flash rate predicted by the precipitation ice mass is $1-6 \mathrm{fl} . \mathrm{min}^{-1}$ for the west storm cell and $1-3$ fl. $\min ^{-1}$ for the center cell, which are both greater than the $0.5-2.0 \mathrm{fl} . \mathrm{min}^{-1}$ for the east cell.

[44] Analysis of the three storm cells in the $3 \mathrm{~km}$ domain provides an idea of how the storm parameters compared to the finer resolution domain and the ability of these storm parameters to predict lightning flash rate at a coarser resolution. Note that the $3 \mathrm{~km}$ resolution domain does not provide a perfect comparison of a coarser resolution simulation to a fine resolution simulation, because the two-way nesting allows the fine resolution domain to influence the meteorology in the coarser resolution domain. As might be expected, the peak updraft velocities were much weaker for the $3 \mathrm{~km}$ resolution domain $\left(1-9 \mathrm{~m} \mathrm{~s}^{-1}\right)$ compared to the $1 \mathrm{~km}$ resolution domain. For the coarser domain, the updrafts were weaker and the amount of ice was similar compared to these parameters in the $1 \mathrm{~km}$ resolution domain. However, we find the flash rates to be similar in value to those predicted on the $1 \mathrm{~km}$ domain. Although the updrafts are weaker in the $3 \mathrm{~km}$ domain compared to the $1 \mathrm{~km}$ domain, the $w_{\max }$, updraft volume, and flux product values input into the storm parameter-lightning equations are all controlled by the intercept value of the regression. Thus, it is problematic to infer the lightning flash rate for weak thunderstorms pro-

Figure 8. Temporal evolution of the modeled flash rates (fl. $\mathrm{min}^{-1}$ ) for the 13 July Alabama storm control and sensitivity simulations derived from the (a) precipitation ice mass, (b) ice water path, (c) precipitation and nonprecipitation ice mass flux product, (d) updraft volume, (e) maximum vertical velocity, and (f) cloud top height. In Figure 8e the dashed lines are the flash rate derived from the BB08 equation. The black line is the control simulation (east storm cell, $\Delta \mathrm{x}=1 \mathrm{~km}$ ), the blue line is the center storm cell, and the red line is the west storm cell. The black, blue, and red crosses are the east, center, and west (respectively) storm cells at $\Delta \mathrm{x}=3 \mathrm{~km}$ horizontal resolution plotted at different times to be seen more easily. In Figure 8e, the black, blue, and red open circles are the east, center, and west storm cells, respectively, at $\Delta \mathrm{x}=3 \mathrm{~km}$ for the BB08 equation plotted at different times to be seen more easily. 
ducing less than $10 \mathrm{fl}$. $\mathrm{min}^{-1}$ using storm parameters based on dynamical parameters.

\section{Discussion}

[45] Lightning flash rate was inferred for the 10 July STERAO-A and the 13 July 2005 Alabama storm from different microphysical and dynamical model parameters, namely, ice water path, precipitation ice mass, updraft volume with $w>5 \mathrm{~m} \mathrm{~s}^{-1}$, ice mass flux product, maximum vertical velocity, and cloud top height. For these two simulated storms, the most reliable parameters to predict lightning rate appear to be the precipitation ice mass and the maximum vertical velocity using the PR92 equation. Inferred lightning rates from all other parameters are accompanied by larger uncertainty.

[46] The results from the different storm parameters depend on how well the storm characteristics, including total storm volume, morphology, microphysics, and dynamics were simulated. Parameters that rely more heavily on the accurate forecasts of multiple storm characteristics may not be as robust to model errors as more simple parameters. Thus it might not be surprising that the maximum updraft velocity is the most reliable parameter because it does not depend directly on storm volume, morphology, and microphysical parameterizations, unlike the other parameters, such as the flux product or the precipitation ice mass.

[47] The ability of each of the storm parameters to predict lightning flash rate is now discussed in more detail. For the maximum updraft velocity, based on the calculations in this study, it is evident that the Price and Rind [1992] equation, when scaled properly, sufficiently predicts the flash rate for the severe storm in the U.S. High Plains. The scaling factor is appropriate because the Price and Rind [1992] study used data on a $5 \mathrm{~km}$ resolution, while the model simulations are conducted on different horizontal resolutions. It is interesting that the scaling factor for the 10 July storm is roughly the ratio of the model resolution to the resolution used by Price and Rind [1992]. For the airmass thunderstorms observed and modeled in the Alabama region, the PR92 equation underpredicts the flash rate by a factor of 3 or more. For these weaker storms, there is a need for a more robust relationship.

[48] The flash rate magnitude estimated from the cloud top height is similar to the observed one for the 13 July storm (3-5 fl. $\min ^{-1}$ estimated versus $1-4 \mathrm{fl} . \mathrm{min}^{-1}$ observed). In the case of the 10 July STERAO storm, the estimated flash rate does not exceed $14 \mathrm{fl} . \mathrm{min}^{-1}$, and the observed flash rate trend is poorly replicated.

[49] For the model-calculated $I W P$, we find the computation to be sensitive to the reflectivity threshold that limits the region where $I W P$ is computed. Evidence of where this may be important is seen by comparing radar reflectivity from CSU-CHILL radar with model output, which indicates that the model predicts higher reflectivity in the anvil region than observed. If the reflectivity threshold is increased to $25 \mathrm{dBZ}$ and $30 \mathrm{dBZ}$ to reduce the area over which $I W P$ is computed in the model, the resulting ice water path is then increased (see section 2.2).

[50] As explained by Deierling [2006] and Deierling et al. [2008], the ice mass flux product, updraft volume, and precipitation ice mass are good candidates for predicting lightning flash rate because both the microphysics and dynamics of the storm have strong relationships to thunderstorm electrification resulting in lightning discharges. However, in the current study, predictions of flash rate from these parameters result in higher uncertainty than from the maximum updraft velocity. The variances found are probably due to a combination of errors from the model and the observations. As an example, using a bulk-water microphysics parameterization introduces errors in the computation of ice mass because of the simplistic depiction of the hydrometeor classes (e.g., cloud particle size and size distributions) and the assumptions associated with many of the microphysical processes (e.g., autoconversion rate and ice initiation processes). A comparison of results from different microphysics schemes showed that there is a $15-60 \%$ variation in the results, depending on which storm parameter is used for the calculation. Also, the computation of the ice mass trends from the observed radar data depends on the assumption of the particular cloud particle size distributions used in the calculation. This can lead to a variance of the ice mass trends by an order of magnitude [Deierling, 2006; Deierling et al., 2008]. Moreover, the number of hydrometeor categories and their characteristics detected by the radar and predicted by WRF are different, which may also lead to differences in the values of ice mass.

[51] We also performed calculations of the lightning potential index (LPI, Yair et al. [2010]) to see if the modelderived $L P I$ is correlated with the observed lightning flash rate. The $L P I$ is appropriate for cloud-resolving models and is a function of the condensate mixing ratios and vertical velocity between 0 and $-20^{\circ} \mathrm{C}$.

$$
L P I=\frac{1}{V} \iiint \frac{2 \sqrt{q_{\text {ice }} q_{\text {liq }}}}{\left(q_{\text {ice }}+q_{\text {liq }}\right)} w^{2} d x d y d z,
$$

where $q_{i c e}$ is the ice fractional mixing ratio $\left(\mathrm{kg} \mathrm{kg}^{-1}\right)$ dependent on cloud ice, snow, and graupel mixing ratios, $q_{\text {liq }}$ is the total liquid water mixing ratio $\left(\mathrm{kg} \mathrm{kg}^{-1}\right), w$ is vertical velocity, and $V$ is the total volume of air in the layer.

[52] We find that the trend of the LPI for the 10 July STERAO-A storm is similar to the trend of the observed lightning flash rate for the transition and supercell stage (i.e., LPI increases from the transition to supercell stage). However, the $L P I$ trend during the multicell stage is decreasing substantially, which is very different from the trend of the observed flash rate during the multicell stage. This behavior is true for the control and sensitivity simulations. The LPI for the 13 July Alabama storm matches the observed lightning flash rate trend very well for the east storm cell, but less so for the other two storm cells. In summary, the LPI has the potential to be a good proxy for lightning flash rate.

\section{Conclusions}

[53] The potential for some model parameters to be used as a proxy for the total lightning rate in cloud-resolving model studies has been investigated in two different storms: the 10 July 1996 STERAO-A severe storm that occurred in the U.S. High Plains and the 13 July 2005 airmass thunderstorm near Huntsville, Alabama. It has been shown that the WRF model reproduces the main features of the radar 
reflectivity well, in particular the transition from a multicell to a supercell in the STERAO-A storm.

[54] Different microphysical and dynamical model parameters have been tested as proxies for lightning flash rate. The IWP parameter overpredicts the observed lightning flash rate, especially for the Alabama airmass thunderstorm. Given the sensitivity of IWP to model calculations of radar reflectivity, predicting flash rates inferred from IWP is problematic. The precipitation ice mass parameter reproduces the trend of the observed lightning flash rate, but overpredicts the magnitude for the severe storm. The updraft volume parameter substantially underpredicts the lightning flash rate magnitude for both types of storms. The PR92 power law predicts the lightning flash rate magnitude fairly well. The trend predicted by the PR92 equation is similar to that observed for the severe storm, but predicts the increase in flash rate during the transition stage rather than at the beginning of the supercell stage. For the Alabama airmass thunderstorm, the PR92 equation substantially underpredicts the flash rate. Thus, the PR92 equation is less reliable for weaker storms and is less robust a parameter because of its dependence on the horizontal resolution of the simulation. The cloud top height predicts the flash rate for the 13 July airmass storm well, but poorly replicates the observed flash rate for the 10 July storm. The ice mass flux product tends to predict the trend of the lightning flash rate especially for the severe storm, but the flash rate magnitude is not similar to observations for either storm. While the ice mass flux product is likely to be a good proxy for lightning flash rate because it embodies both dynamical and microphysical aspects of the storm, further work needs to be done to improve its accuracy.

[55] For this study, only two storms have been tested, and more case studies are needed to get reliable and robust relationships between the total lightning activity and the model parameters. It is also necessary to sample a large variety of storms of different types (single cells, supercell, multicell, mesoscale convective system, and hurricanes) and from different regions (midlatitudes/tropics and maritime/ continental). A dedicated study on predicting flash rate in less intense storms is especially needed.

[56] Acknowledgments. The National Center for Atmospheric Research is operated by the University Corporation for Atmospheric Research under the sponsorship of the National Science Foundation. The authors thank Sarah Tessendorf and Hugh Morrison for their comments on the manuscript and offer special thanks to Barry Lynn for his advice on computing the LPI.

\section{References}

Allen, D. J., and K. E. Pickering (2002), Evaluation of lightning flash rate parameterizations for use in a global chemical transport model, J. Geophys. Res., 107(D23), 4711, doi:10.1029/2002JD002066.

Altaratz, O., T. Reisin, and Z. Levin (2005), Simulation of the electrification of winter thunderclouds using the three-dimensional regional atmospheric modeling system (RAMS) model: Single cloud simulations, J. Geophys. Res., 110, D20205, doi:10.1029/2004JD005616.

Barth, M. C., A. L. Stuart, and W. C. Skamarock (2001), Numerical simulations of the July 10, 1996, Stratospheric-Tropospheric Experiment: Radiation, Aerosols, and Ozone STERAO-Deep convection experiment storm: Redistribution of soluble tracers, J. Geophys. Res., 106(D12), 12,381-12,400, doi:10.1029/2001JD900139.

Barth, M. C., S.-W. Kim, W. C. Skamarock, A. L. Stuart, K. E. Pickering, and L. E. Ott (2007a), Simulations of the redistribution of formaldehylde, formic acid, and peroxides in the July 10, 1996 STERAO deep convection storm, J. Geophys. Res., 112, D13310, doi:10.1029/2006JD008046.

Barth, M. C., et al. (2007b), Cloud-scale model intercomparison of chemical constituent transport in deep convection, Atmos. Chem. Phys., 7, 4709-4731.

Barthe, C., and M. C. Barth (2008), Evaluation of a new lightningproduced $\mathrm{NO}_{\mathrm{x}}$ parameterization for cloud resolving models and its associated uncertainties, Atmos. Chem. Phys., 8, 4691-4710.

Barthe, C., and J.-P. Pinty (2007a), Simulation of a supercellular storm using a three-dimensional mesoscale model with an explicit lightning flash scheme, J. Geophys. Res., 112, D06210, doi:10.1029/2006JD007484.

Barthe, C., and J.-P. Pinty (2007b), Simulation of electrified storms with comparison of the charge structure and lightning efficiency, J. Geophys. Res., 112, D19204, doi:10.1029/2006JD008241.

Barthe, C., J.-P. Pinty, and C. Mari (2007), Lightning-produced $\mathrm{NO}_{\mathrm{x}}$ in an explicit electrical scheme tested in a Stratospheric-Tropospheric Experiment: Radiation, aerosols, and ozone case study, J. Geophys. Res., 112, D04302, doi:10.1029/2006JD007402.

Blyth, A. M., H. J. C. Jr., K. Driscoll, A. M. Gadian, and J. Latham (2001), Determination of ice precipitation rates and thunderstorm anvil ice contents from satellite observations of lightning, Atmos. Res., 59-60, 217-229.

Boccippio, D. J. (2002), Lightning scaling relations revisited, J. Atmos. Sci., 59, 1086-1104.

Brunkow, D., V. N. Bringi, P. C. Kennedy, S. A. Rutledge, V. Chandrasekar, E. A. Mueller, and R. K. Bowie (2000), A description of the CSU-CHILL national radar facility, J. Atmos. Oceanic Technol., 17, 1596-1608.

Carey, L. D., and S. A. Rutledge (1996), A multiparameter radar case study of the microphysical and kinematic evolution of a lightning producing storm, Meteor. Atmos. Phys., 59, 33-64.

Chen, F., and J. Dudhia (2001), Coupling an advanced land-surface/hydrology model with the Penn State/NCAR MM5 modeling system. Part I: Model description and implementation, Mon. Weather Rev., 129, 569-585.

Crook, N. A., and J. Sun (2004), Analysis and forecasting of the low-level wind during the Sidney 2000 forecast demonstration project, Weather Forecast., 19, 151-167.

Defer, E., P. Blanchet, C. Théry, P. Laroche, J. E. Dye, M. Venticinque, and K. L. Cummins (2001), Lightning activity for the July 10, 1996, storm during the Stratosphere-Troposphere Experiment: Radiation, Aerosol, and Ozone-A (STERAO-A) experiment, J. Geophys. Res., 106, 10,151-10,172, doi:10.1029/2000JD900849.

Deierling, W. (2006), The relationship between total lightning and ice fluxes, Ph.D. thesis, University of Alabama, Huntsville, Alabama.

Deierling, W., and W. A. Petersen (2008), Total lightning activity as an indicator of updraft characteristics, J. Geophys. Res., 113, D16210, doi:10.1029/2007JD009598.

Deierling, W., W. A. Petersen, J. Latham, S. M. Ellis, and H. J. Christian (2005), On the relationship of thunderstorm ice hydrometeor characteristics and total lightning measurements, Atmos. Res., 76, 114-126.

Deierling, W., W. A. Petersen, J. Latham, S. Ellis, and H. J. Christian (2008), The relationship between lightning activity and ice fluxes in thunderstorms, J. Geophys. Res., 113, D15210, doi:10.1029/2007JD009700.

Dudhia, J. (1989), Numerical study of convection observed during the winter monsoon experiment using a mesoscale two-dimensional model, J. Atmos. Sci., 46, 3077-3107.

Dye, J. E., J. J. Jones, and W. P. Winn (1989), Observations within two regions of charge during initial thunderstorm electrification, Quart. J. R. Meteor. Soc., 114, 1271-1290.

Dye, J. E., et al. (2000), An overview of the Stratospheric-Tropospheric Experiment: Radiation, Aerosols, and Ozone (STERAO)-Deep Convection experiment with results for the July 10, 1996 storm, J. Geophys. Res., 105, 10,023-10,045, doi:10.1029/1999JD901116.

Emmons, L. K., et al. (2010), Description and evaluation of the model for ozone and related chemical tracers, version 4 (MOZART-4), Geosci. Model Dev., 3, 43-67.

Fehr, T., H. Höller, and H. Huntrieser (2004), Model study on production and transport of lightning-produced $\mathrm{NO}_{\mathrm{x}}$ in a EULINOX supercell storm, J. Geophys. Res., 109, D09102, doi:10.1029/2003JD003935.

Goodman, S. J., et al. (2005), The North Alabama Lightning Mapping Array: Recent severe storm observations and future prospects, Atmos. Res., 76, 423-437.

Grewe, V., D. Brunner, M. Dameris, J. L. Grenfell, R. Hein, D. Shindell, and J. Staehelin (2001), Origin and variability of upper tropospheric nitrogen oxides and ozone at northern mid-latitudes, Atmos. Env., 35, 3421-3433

Helsdon, J. H., G. Wu, and R. D. Farley (1992), An intracloud lightning parameterization scheme for a storm electrification model, J. Geophys. Res., 97, 5865-5884, doi:10.1029/92JD00077. 
Helsdon, J. H., W. A. Wojcik, and R. D. Farley (2001), An examination of thunderstorm-charging mechanism using a two-dimensional storm electrification model, J. Geophys. Res., 106, 1165-1192, doi:10.1029/ 2000JD900532.

Horowitz, L. W., et al. (2003), A global simulation of tropospheric ozone and related tracers: Description and evaluation of MOZART, version 2, J. Geophys. Res., 108(D24), 4784, doi:10.1029/2002JD002853.

Hudman, R. C., et al. (2007), Surface and lightning sources of nitrogen oxides over the United States: Magnitudes, chemical evolution, and outflow, J. Geophys. Res., 112, D12S05, doi:10.1029/2006JD007912.

Jayaratne, R., C. P. R. Saunders, and J. Hallett (1983), Laboratory studies of the charging of soft hail during ice crystal interactions, Quart. J. R. Meteor. Soc., 103, 609-630.

Jourdain, L., S. S. Kulawik, H. M. Worden, K. E. Pickering, J. Worden, and A. M. Thompson (2010), Lightning $\mathrm{NO}_{x}$ emissions over the USA constrained by TES ozone observations and the GEOS-Chem model, Atmos. Chem. Phys., 10, 107-119.

Kain, J. S., and J. M. Fritsch (1990), A one-dimensional entraining/ detraining plume model and its application in convective parameterization, J. Atmos. Sci., 47, 2784-2802.

Kain, J. S., and J. M. Fritsch (1993), Convective Parameterization for Mesoscale Models: The Kain-Fritcsh Scheme, The Representation of Cumulus Convection in Numerical Models, 246 pp., K. A. Emanuel and D.J. Raymond, Eds., Amer. Meteor. Soc.

Kuhlman, K. M., C. L. Ziegler, E. R. Mansell, D. R. MacGorman, and J. M. Straka (2006), Numerically simulated electrification and lightning of the 29 June 2000 STEPS supercell storm, Mon. Weather Rev., 134(10), 2734-2757.

Lang, T. J., and S. A. Rutledge (2002), Relationships between convective storm kinematics, precipitation, and lightning, Mon. Weather Rev., 130, 2492-2506.

Laroche, P., A. Bondiou, P. Blanchet, and J. Pigère (1994), 3D VHF mapping of lightning discharge within a storm, paper presented at Foudre et Montagne 94, Chamonix, France.

Latham, J., W. A. Petersen, W. Deierling, and H. J. Christian (2007), Field identification of a unique globally dominant mechanism of thunderstorm electrification, Quart. J. R. Meteor. Soc., 133, 1453-1457.

Lin, Y.-L., R. D. Farley, and H. D. Orville (1983), Bulk parameterization of the snow field in a cloud model, J. Clim. Appl. Meteor., 22, 1065-1092.

Mansell, E., D. R. MacGorman, C. L. Ziegler, and J. M. Straka (2005), Charge structure and lightning sensitivity in a simulated multicell thunderstorm, J. Geophys. Res., 110, D12101, doi:10.1029/2004JD005287.

Mansell, E. R., D. MacGorman, C. L. Ziegler, and J. M. Straka (2002), Simulated three-dimensional branched lightning in a numerical thunderstorm model, J. Geophys. Res., 107(D9), 4075, doi:10.1029/ 2000JD000244.

McCaul, E. W., S. J. Goodman, K. M. LaCasse, and D. J. Cecil (2009), Forecasting lightning threat using cloud-resolving model simulations, Weather Forecast., 24, 709-729.

Meijer, E. W., P. F. J. vanVelthoven, D. W. Brunner, H. Huntrieser, and H. Kelder (2001), Improvement and evaluation of the parameterization of nitrogen oxide production by lightning, Phys. Chem. Earth (C), 26 , 577-583.

Mohr, C. G., L. J. Miller, R. L. Vaughn, and H. W. Frank (1986), On the merger of mesoscale datasets into a common Cartesian format for efficient and systematic analysis, J. Atmos. Oceanic Technol., 3, 143-161.

Noh, Y., W. G. Cheon, and S. Raasch (2001), The improvement of the K-profile model for the PBL using LES, in Int. Workshop of Next Generation NWP Models, pp. 65-66, Laboratory for Atmospheric Modeling Research, Seoul, South Korea.

Ott, L. E., K. E. Pickering, G. L. Stenchikov, D. J. Allen, A. J. DeCaria B. Ridley, R.-F. Lin, S. Lang, and W.-K. Tao (2010), Production of lightning $\mathrm{NO}_{\mathrm{x}}$ and its vertical distribution calculated from three-dimensional cloud-scale chemical transport model simulations, J. Geophys. Res., 115, D04301, doi:10.1029/2009JD011880.

Petersen, W. A., S. A. Rutledge, R. C. Cifelli, B. S. Ferrier, and B. F. Smull (1999), Shipborne dual-Doppler operations during TOGA-COARE: Integrated observations of storm kinematics and electrification, Bull. Am. Meteorol. Soc., 80, 81-96.

Petersen, W. A., H. J. Christian, and S. A. Rutledge (2005a), TRMM observations of the global relationship between ice water content and lightning, Geophys. Res. Lett., 32, L14819, doi:10.1029/2005GL023236.

Petersen, W. A., et al. (2005b), The UAH-NSSTC/WHNT ARMOR C-band dual-polarimetric radar: A unique collaboration in research, education and technology transfer, in 32nd AMS Radar Meteorology Conference, American Meteorological Society, Albuquerque, NM.

Pickering, K. E., Y. Wang, W. K. Tao, C. Price, and J.-F. Müller (1998), Vertical distributions of lightning $\mathrm{NO}_{\mathrm{x}}$ for use in regional and global chemical transport models, J. Geophys. Res., 103(D23), 31,20331,216, doi:10.1029/98JD02651.

Price, C., and D. Rind (1992), A simple lightning parameterization for calculating global lightning distributions, J. Geophys. Res., 97, 9919-9933, doi:10.1029/92JD00719.

Prigent, C., E. Defer, J. R. Pardo, C. Pearl, W. B. Rossow, and J. P. Pinty (2005), Relations of polarized scattering signatures observed by the TRMM Microwave Instrument with electrical processes in cloud systems, Geophys. Res. Lett., 32, L04810, doi:10.1029/2004GL022225.

Reynolds, S. E., M. Brooks, and M. F. Gourley (1957), Thunderstorm charge separation, J. Meteor., 14, 163-178.

Rutledge, S. A., E. R. Williams, and T. D. Keenan (1992), The down under Doppler and electricity experiment (DUNDEE): Overview and preliminary results, Bull. Am. Meteorol. Soc., 73, 3-16.

Salzmann, M., M. G. Lawrence, V. T. J. Phillips, and L. J. Donner (2008), Cloud system resolving model study of the roles of deep convection for photochemistry in the TOGA COARE/CEPEX region, Atmos. Chem. Phys., 8, 2741-2757.

Saunders, C. P. R., W. D. Keith, and R. P. Mitzeva (1991), The effect of liquid water on thunderstorm charging, J. Geophys. Res., 96, 11,00711,017, doi:10.1029/91JD00970.

Skamarock, W. C., J. G. Powers, M. Barth, J. E. Dye, T. Matejka, D. Bartels, K. Baumann, J. Stith, D. D. Parrish, and G. Hubler (2000), Numerical simulations of the July 10 stratospheric-tropospheric experiment: Radiation, aerosol, and ozone/deep convection experiment convective system: Kinematics and transport, J. Geophys. Res., 105, 19,973-19,990, doi:10.1029/2000JD900179.

Skamarock, W. C., J. E. Dye, E. Defer, M. C. Barth, J. L. Stith, and B. A Ridley (2003), Observational- and modeling-based budget of lightningproduced $\mathrm{NO}_{\mathrm{x}}$ in a continental thunderstorm, J. Geophys. Res., 108(D10), 4305, doi:10.1029/2002JD002163.

Skamarock, W. C., J. B. Klemp, J. Dudhia, D. Gill, D. Barker, W. Wang, and J. G. Powers (2005), A description of the Advanced Research WRF Version 2, Tech. Rep., NCAR, Boulder, Colorado.

Straka, J. M., D. S. Zrnic, and A. V. Ryshkov (2000), Bulk hydrometeor classification and quantification using polarimetric radar data: Synthesis of relations, J. Appl. Meteor., 39, 1341-1372.

Sun, J., and N. A. Crook (1997), Dynamical and microphysical retrieval from Doppler radar observations using a cloud model and its adjoint. Part I: Model development and simulated data experiments, J. Atmos. Sci., 55 , $835-852$

Sun, J., and N. A. Crook (2001), Real-time low-level wind and temperature analysis using single WSR-88D data, Weather Forecast., 16, 117-132.

Takahashi, T. (1978), Riming electrification as a charge generation mechanism in thunderstorms, J. Atmos. Sci., 35, 1536-1548.

Thompson, G., R. M. Rasmussen, and K. Manning (2004), Explicit forecasts of winter precipitation using an improved bulk microphysics scheme. Part I: Description and sensitivity analysis, Mon. Weather Rev., 132, 519-542.

Ushio, T., S. J. Heckman, D. J. Boccippio, and H. J. Christian (2001), A survey of thunderstorm flash rates compared to cloud top height using TRMM satellite data, J. Geophys. Res., 106(D20), 24,089-24,095, doi:10.1029/2001JD900233.

Vivekanandan, J., D. S. Zrnic, S. M. Ellis, R. Oye, A. V. Ryzhkov, and J. Straka (1999), Cloud microphysics retrieval using S-band dualpolarization radar measurements, Bull. Am. Meteorol. Soc., 80, 381-388. Vonnegut, B. (1963), Some facts and speculations concerning the origin and role of thunderstorm electricity, Meteorol. Monogr., 5, 224-241.

Wang, C., and R. Prinn (2000), On the roles of deep convection clouds in tropospheric chemistry, J. Geophys. Res., 105, 3399-3418, doi:10.1029/ 2000JD900263.

Wicker, L. J., and W. C. Skamarock (2002), Time-splitting methods for elastic models using forward time schemes, Mon. Weather Rev., 130, 2088-2097.

Wiens, K. C., S. A. Rutledge, and S. A. Tessendorf (2005), The 29 June 2000 supercell observed during STEPS. Part II: Lightning and charge structure, J. Atmos. Sci., 62, 4151-4177.

Williams, E. R. (1985), Large-scale charge separation in thunderclouds, J. Geophys. Res., 90(D4), 6013-6025, doi:10.1029/JD090iD04p06013.

Williams, E. R., and R. M. Lhermitte (1983), Radar tests of the precipitation hypothesis for thunderstorm electrification, J. Geophys. Res., 88 10,984-10,992, doi:10.1029/JC088iC15p10984.

Yair, Y., B. Lynn, C. Price, V. Kotroni, K. Lagouvardos, E. Morin, A. Magnai, and M. del Carmen Llasat (2010), Predicting the potential for lightning activity in Mediterranean storms based on the Weather Research and Forecasting (WRF) model dynamic and microphysical fields, J. Geophys. Res., 115, D04205, doi:10.1029/2008JD010868.

Yoshida, S., T. Morimoto, T. Ushio, and Z. Kawasaki (2009), A fifthpower relationship for lightning activity from Tropical Rainfall Measur- 
ing Mission satellite observations, J. Geophys. Res., 114, D09104, doi:10.1029/2008JD010370.

C. Barthe, Laboratoire de l'Atmosphère et des Cyclones, CNRS, MétéoFrance, Université de La Réunion, 15 Ave. René Cassin, BP 7151, 97715

Saint-Denis Cedex 9, La Réunion, France. (christelle.barthe@meteo.fr)
M. C. Barth and W. Deierling, National Center for Atmospheric Research, PO Box 3000, Boulder, CO 80307, USA. 